\title{
El Tribunal Constitucional de República Dominicana EN LA PERSPECTIVA COMPARATIVA CON LOS TRIBUNALES CONSTITUCIONALES LATINOAMERICANOS*
}

\author{
Humberto Nogueira AlCALÁ ${ }^{* *}$
}

RESUMEN: El presente artículo analiza la incorporación al Derecho Constitucional latinoamericano del décimo Tribunal Constitucional de la región, que es el Tribunal previsto en la Constitución de República Dominicana de 2010, realizando un análisis comparativo de su estatuto jurídico y competencias, como asimismo de las modalidades y efectos de sus sentencias.

PALABRAS CLAVE: Tribunal Constitucional - Estatuto jurídico y competencias - Sentencia constitucional - Derecho Constitucional comparado

\section{The Dominican Republic Constitutional CourT IN THE COMPARATIVE PERSPECTIVE WITH THE LATINAMERICAN CONSTITUTIONAL COURTS}

\begin{abstract}
This article analyzes the incorporation of the tenth Constituional Court of the Region to the Latinamerican Constitutional Law, which is the Court foreseen in the 2010 Constitution of the Dominican Republic. The article performs a comparative analysis of its juridical statute and competences, as well as the modalities and effects of its sentences.
\end{abstract}

KEY WORDS: Constitutional Court - Juridical Statute and competences - Constitutional sentence - Comparative Constitutional Law.

\footnotetext{
* Este artículo constituye una versión afinada de la ponencia presentada en el XVII Encuentro Iberoamericano de Derecho Procesal Constitucional, celebrado en Santo Domingo, República Dominicana, el 2, 3 y 4 de marzo de 2011.

Fecha de recepción: 18 de junio de 2011.

Fecha de aceptación: 24 de octubre de 2011.

** El autor es Abogado, Doctor en Derecho por la Universidad Católica de Lovaina La Nueva (Bélgica). Profesor Titular de Derecho Constitucional Universidad de Talca (Chile), Director Ejecutivo del Centro de Estudios Constitucionales de Chile, Presidente de la Asociación Chilena de Derecho Constitucional; Vicepresidente del Instituto Iberoamericano de Derecho Procesal Constitucional. Correo electrónico: Nogueira@utalca.cl
} 


\section{INTRODUCCIÓN}

Podemos sostener que el nuevo Tribunal Constitucional establecido en la Constitución de 2010 de la República Dominicana ${ }^{1}$ es el décimo en la realidad latinoamericana en el inicio de la segunda década del siglo XXI, este se agrega a los ya establecidos en las Constituciones de Bolivia, Colombia, Chile, Ecuador, Guatemala y Perú, agregando a este grupo la Sala Constitucional de la Corte Suprema de Costa Rica; la Sala Constitucional de la Corte Suprema de El Salvador, la Sala Constitucional del Tribunal Supremo de Justicia de Venezuela que son también auténticos Tribunales Constitucionales, en la medida que ejercen jurisdicción exclusivamente constitucional, no tienen competencia en ámbitos de jurisdicción ordinaria, tienen plena autonomía jurisdiccional, su potestad jurisdiccional no es revisada por otro tribunal interno ni por el pleno de la Corte Suprema, ni su competencia puede ser atraída por el Tribunal pleno de la Corte Suprema, a petición de algunos de sus miembros, como sucede en el caso de Paraguay, o parte del ámbito de la jurisdicción constitucional normativa sea competencia de la Corte Suprema en pleno, como ocurre en Nicaragua ${ }^{2}$.

Para concretar el análisis, además del texto de la Constitución de la República Dominicana, se tendrá en consideración la Ley No 137-11 Orgánica Constitucional del Tribunal Constitucional y de los Procedimientos Constitucionales promulgada recientemente el 13 de junio de 2011, la que pudo concretarse mediante un acuerdo del gobierno con el partido Revolucionario Dominicano que había hecho presente diversas observaciones al proyecto de ley, por lo cual se pactó la reforma de dicha ley por la Ley No 145-11 promulgada el 4 de julio de 2011, la que tiene por finalidad modificar la ley anterior en algunas de sus disposiciones las cuales, como determina el considerando segundo, de esta última ley "no satisfacen las expectativas de una parte de nuestra clase política y de la ciudadanía en general, pero sí como, para corregir algunos artículos que contienen errores al referirse a otros artículos del texto de la Ley”.

El presente artículo constituye una versión modificada y actualizada de otro presentado en el Encuentro Iberoamericano de Derecho Procesal Constitucional Santo Domingo, República Dominicana, 2-4 marzo de 2011, organizado por el Instituto Iberoamericano de Derecho Procesal Constitucional, al cual el autor fue invitado como ponente cuando aún

1 Constitución proclamada el 16 de enero de 2010, y publicada en la Gaceta Oficial No. 10561, del 26 de enero de 2010.

2 Para el concepto y caracterización de los tribunales constitucionales ver: Nogueira Alcalá, Humberto. (2006), Justicia y tribunales constitucionales en América del Sur. Caracas: Editorial Jurídica Venezolana, 313 pp. pp. 61 - 66. Hay edición anterior en México: Ed. Porrúa. Biblioteca Porrúa de Derecho Procesal Constitucional. 
no se aprobaba la Ley Orgánica del Tribunal Constitucional de República Dominicana. Cabe finalmente señalar que si bien la normativa que rige al tribunal se encuentra ya en condiciones de operar, aún no se han determinado los jueces del Tribunal Constitucional, los que a fines de este mes de octubre de 2011, aún se encuentran en el proceso de elección por parte del Consejo de la Magistratura, por lo que el Tribunal Constitucional aún no entra en funciones.

Finalmente, señalemos que la instauración de un sistema de jurisdicción Constitucional es indispensable para un Estado Constitucional Democrático a inicios del siglo XXI, para el respeto de la fuerza normativa de la constitución por los poderes constituidos, para el respeto irrestricto de los derechos fundamentales y para la resolución de conflictos de competencia. Por otra parte es necesario destacar la fuerza con que se han desarrollado los tribunales constitucionales en América Latina en las últimas décadas, como seńaláramos anteriormente, ya tenemos diez tribunales constitucionales en el subcontinente.

\section{1) El concepto de Tribunal Constitucional}

En tal perspectiva, señalamos que los Tribunales o Cortes Constitucionales son órganos supremos constitucionales de unica instancia, de carácter permanente, independientes e imparciales, que tienen por función esencial y exclusiva la interpretación y defensa jurisdiccional de la Constitución, a través de procedimientos contenciosos constitucionales referentes como núcleo esencial a la constitucionalidad de normas infraconstitucionales y la distribución vertical y horizontal del poder estatal, agregándose generalmente la protección extraordinaria de los derechos fundamentales, que actuan en base a razonamientos juridicos y cuyas sentencias tienen valor de cosa juzgada, pudiendo expulsar del ordenamiento jurídico las normas consideradas inconstitucionales.

Consideramos que un Tribunal Constitucional es un órgano jurisdiccional que tiene como competencia exclusiva lo contencioso constitucional, por tanto no tiene competencias propias de jurisdicción ordinaria en materia civil o criminal u otras materias.

Asimismo, un Tribunal Constitucional no tiene como elemento esencial de su calificación, un control monopólico de constitucionalidad de las leyes. Este elemento no nos parece indispensable si el Tribunal ejerce un contencioso constitucional sustantivo sobre la materia en el respectivo Estado, al determinar sobre la incorporación de los preceptos legales al ordenamiento jurídico (control preventivo o a priori) o su expulsión del mismo ordenamiento (control represivo o a posterior:), pudiendo existir otros órganos jurisdiccionales que realizan control de constitucionalidad 
de preceptos legales con efectos inter partes o de inaplicación al caso concreto, como ocurre en América del Sur en países que tienen Tribunales Constitucionales como es el caso de Colombia, Perú y Ecuador. En todo caso, hay una excepción generalizada respecto de las leyes preconstitucionales, las cuales sin perjuicio de estar sujetas al control del Tribunal Constitucional, pueden ser objeto de control por parte los tribunales ordinarios de justicia determinando su derogación tácita, como ocurre también en algunas jurisdicciones europeas, entre otras, la espańola.

A su vez, este núcleo material básico de jurisdicción y procedimiento constitucional, no es incompatible con otras funciones adicionales que tienen los tribunales constitucionales, siempre y cuando versen sobre elementos del concepto material de constitución y de delimitación del poder politico, aunque ellas no sean esenciales, las cuales se denominan generalmente competencias residuales.

Los Tribunales Constitucionales los integran jueces letrados nombrados por las autoridades politicas (Gobierno, Congreso Nacional y, eventualmente, la Corte Suprema o las jurisdicciones superiores del Estado), no siendo en su mayoría magistrados de carrera ${ }^{3}$, todo ello refuerza la legitimidad política del Tribunal, sin descuidar la legitimidad jurídica.

En nuestra perspectiva no es una caracteristica esencial a un Tribunal o Corte Constitucional el situarse como órgano extrapoder, ya que eventualmente puede formar parte del Poder Judicial, siempre y cuando disponga de independencia funcional y no ejerza competencias de jurisdicción ordinaria, pudiendo hacer respetar sus fallos a la Corte Suprema o las demás salas de la misma, como ocurre entre otros tribunales constitucionales como el de Colombia y con la Sala Constitucional del Tribunal Supremo de Venezuela, en América del Sur ${ }^{4}$ y la Sala Constitucional de la Corte Suprema de Costa Rica.

En todo caso concordamos con Favoreu, en que un Tribunal Constitucional debe ser independiente de cualquier otro poder o autoridad, dotado de un estatuto constitucional que precise su integración, organización y competencias ${ }^{5}$.

Favoreu, Louis. (1994) Los Tribunales Constitucionales. Barcelona: Ed. Ariel, 158 pp. p. 29.

En el mismo sentido, ver Fernández Rodríguez, José Julio. (2002). La Justicia Constitucional Europea ante el siglo XXI. Madrid: Ed. Tecnos, 164 pp. p. 19.

FAVOREU (1994) 28. 


\section{2) LA INTEGRACIÓN Y ESTATUTO JURÍDICO DE LOS MIEMBROS DE LOS TRIBUNALES CONSTITUCIONES}

Los operadores jurisdiccionales de los tribunales constitucionales son sus magistrados. Determinar quiénes son ellos, quién los nombra, de dónde provienen, cuál es su formación jurídica, su estatuto jurídico, son aspectos cruciales de una adecuada concreción de la justicia constitucional. El juez constitucional tiene que ser consciente de la responsabilidad que asume, con una sólida formación y práctica en derecho público y en interpretación constitucional, además de una adecuada experiencia.

\section{1.) EL NÚMERO DE MAGISTRADOS}

El número de magistrados por regla general debe ser impar, lo que posibilita en mejor forma evitar empates y el ejercicio de calidad del voto del Presidente del Tribunal, lo que le otorga una carga política especial. Siendo poco afortunadas y deficientes técnicamente las integraciones de tribunales constitucionales con un número par.

El Tribunal Constitucional de República Dominicana cumple con este estándar, ya que el artículo 186 de la Constitución determina que dicho órgano estará integrado por trece miembros.

El número de magistrados debe ser acorde con el ámbito de competencias y la cantidad de trabajo que tenga el Tribunal Constitucional. La cantidad de cinco o siete magistrados puede ser compatible con un órgano que tenga escasas atribuciones en materia de control de constitucionalidad, como asimismo, por el limitado número de órganos o agentes que pueden plantear cuestiones para ser resueltas por el Tribunal Constitucional. En el caso latinoamericano, el número de jueces no tiene una relación directa con el número de competencias del tribunal.

\section{(2.2.) EL SISTEMA DE NOMBRAMIENTO, DURACIÓN EN EL CARGO Y PO- SIBLE REELECCIÓN DE LOS MAGISTRADOS DEL TRIBUNAL CONS- TITUCIONAL}

La necesidad de dotar de independencia en el ejercicio de sus funciones jurisdiccionales al Tribunal Constitucional y de imparcialidad a los magistrados que lo integran, hacen necesario que el ordenamiento jurídico contemple ciertas exigencias que eviten la politización contingente de los jueces, consideren una formación y experiencia jurídica sólida de ellos, lo que hace dirigir la mirada sobre el sistema y requisitos para ser nombrado juez del Tribunal Constitucional, la duración del cargo, las posibilidades de reelección, el sistema de incompatibilidades, el régimen de 
inmunidades, como asimismo, el sistema de la elección del Presidente del Tribunal.

La labor jurídica realizada por los tribunales constitucionales que tiene evidentes connotaciones políticas requiere de los magistrados que integran estos tribunales una especial legitimidad doble: su preparación jurídica especializada y su nombramiento por órganos representativos del cuerpo político de la sociedad, los que les transmiten en forma indirecta la legitimidad democrática de su autoridad. Es por ello que los magistrados que integran los tribunales o cortes constitucionales deben ser juristas destacados que cuentan con cierta experiencia mínima exigida, siendo ellos escogidos y nombrados por las asambleas parlamentarias, el Presidente de la República y los gobiernos, en algunos casos, participan también en dichos nombramientos las más altas magistraturas, como ocurre en Italia y en Chile, a manera ejemplar.

\subsection{1.) Los requisitos para ser nombrado magistrado}

En el texto constitucional de República Dominicana se establece en el artículo 187, que para ser juez del Tribunal Constitucional se requieren las mismas condiciones exigidas para los jueces de la Suprema Corte de Justicia, lo que es una norma utilizada en distintos ordenamientos jurídicos de la región.

El artículo 153 de la Constitución determina los requisitos para ser juez o jueza de la Suprema Corte de Justicia se requiere:

1) Ser dominicana o dominicano de nacimiento u origen y tener más de treinta y cinco ańos de edad;

2) Hallarse en pleno ejercicio de los derechos civiles y políticos;

3) Ser licenciado o doctor en Derecho;

4) Haber ejercido durante por lo menos doce ańos la profesión de abogado, la docencia universitaria del derecho o haber desempeñado, por igual tiempo, las funciones de juez dentro del Poder Judicial o de representante del Ministerio Público. Estos períodos podrán acumularse".

Será la ley No 137-11 reformada por la ley 145-11, incorporando al artículo 13 de la ley como requisito para ser elegido juez del Tribunal Constitucional un tope máximo de edad, de "menos de setenta y cinco" años. Es necesario precisar que el mismo artículo 13 de la ley 137-11 determina que la edad de retiro para los jueces del Tribunal Constitucional es de setenta y cinco ańos, lo que posibilitaría elegir magistrados que tuvieran que retirarse solo algunos meses más tarde.

En los tribunales constitucionales latinoamericanos se requiere tener la nacionalidad de origen del respectivo país, a excepción de Chile y Costa Rica, que solo requieren estar en posesión de la nacionalidad sea esta 
de origen o adquirida. Asimismo, en el caso de Venezuela, se exige adicionalmente no tener otra nacionalidad, con lo cual todo venezolano de origen que tenga doble nacionalidad no puede integrar el Tribunal.

La edad minima exigida por los respectivos ordenamientos jurídicos oscila entre 35 años (Bolivia y República dominicana) y 45 años (Ecuador), los demás estatutos jurídicos de los magistrados no ser pronuncian frente a requisitos de edad, pero por la exigencia de al menos diez ańos de ejercicio profesional o académico, se llega fácilmente a un mínimo de 35 años de edad.

Respecto de la calidad de letrados, todos los tribunales exigen ser abogados con a lo menos diez años de ejercicio profesional o actividad académica (Bolivia; Colombia, Costa Rica, Ecuador, El Salvador), doce años en República Dominicana, la exigencia aumenta a quince años en las Cortes o Tribunales Constitucionales de Chile, Ecuador, Guatemala y Perú, como asimismo en la Sala Constitucional del Tribunal Supremo de Venezuela).

Solo Bolivia exige tener una experiencia acreditada en Derecho Público de 8 años.

Algunas Constituciones exigen requisitos adicionales de idoneidad moral y compromiso ciudadano en forma explícita, como son en el caso de Bolivia haber cumplido los deberes militares, no haber sido condenado a pena corporal, salvo rehabilitación concedida por el Senado, ni tener pliego de cargo ejecutoriado. En el caso de Chile, tener los requisitos para ser juez implica estar en ejercicio de los derechos ciudadanos y no haber sido condenado a pena aflictiva; en el caso de Colombia, Costa Rica, Ecuador, El Salvador y Perú ser ciudadano en ejercicio; en Colombia, no haber sido condenado por sentencia judicial a pena privativa de libertad, excepto por delitos políticos o culposos; en Costa Rica, Guatemala, El Salvador y Venezuela, tener reconocida honorabilidad.

Puede sostenerse que todos los magistrados de los Tribunales Constitucionales de América Latina cumplen, al menos formalmente, con los requisitos de idoneidad jurídica básica para desempeñarse adecuadamente en el respectivo órgano jurisdiccional, conociendo y resolviendo las materias sometidas a su conocimiento con criterio jurídico, aun cuando los textos no consideran expresamente una formación en derecho público de los magistrados, con la excepción de Bolivia cuya Constitución de 2009, en su artículo 199, exige tener especialización o experiencia acreditada de por lo menos ocho años en las disciplinas de Derecho Constitucional, Administrativo o Derechos Humanos. 


\subsection{2.) Los órganos que concretan los nombramientos de los magis- trados}

Normalmente los textos constitucionales determinan los órganos y procedimiento a través del cual son elegidos los miembros del Tribunal Constitucional, en el caso de República Dominicana, el texto constitucional determina que es el Consejo de la Magistratura se pronuncia sobre la materia dejando la regulación a una ley, de acuerdo al artículo 189 de la Constitución. Dicha ley regulará los "procedimientos constitucionales y lo relativo a la organización y al funcionamiento del Tribunal Constitucional".

Es la Ley No 137-11 de 2011, Orgánica del Tribunal Constitucional y de los procedimientos constitucionales, la que regula la integración del Tribunal Constitucional determinando, en su artículo 11 que "los jueces del tribunal Constitucional serán designados por el Consejo nacional de la magistratura". Dicho Consejo recibe las propuestas de candidaturas que formulan las organizaciones de la sociedad civil, de los ciudadanos y de entidades públicas y privadas, incluso posibilita que un ciudadano que cumpla con los requisitos puede autoproponerse. Concluido el plazo de estas proposiciones, el Consejo Nacional de la Magistratura publica una relación de las personas propuestas, a fin de que los interesados puedan formular tachas, las que deben acompañarse de las pruebas pertinentes.

El Consejo Nacional de la Magistratura finalmente elige de los candidatos propuestos los trece jueces del Tribunal Constitucional. Dicho Consejo está integrado de acuerdo al Artículo 178 de la Constitución, por ocho miembros: el Presidente de la República, quien lo preside y, en su ausencia, por el Vicepresidente de la República; el Presidente del Senado; un senador o senadora escogido por el Senado que pertenezca al partido o bloque de partidos diferente al del Presidente del Senado y que ostente la representación de la segunda mayoría; el Presidente de la Cámara de Diputados; un diputado o diputada escogido por la Cámara de Diputados que pertenezca al partido o bloque de partidos diferente al del Presidente de la Cámara de Diputados y que ostente la representación de la segunda mayoría; el Presidente de la Suprema Corte de Justicia; un magistrado o magistrada de la Suprema Corte de Justicia escogido por ella misma, quien fungirá de secretario; y el Procurador General de la República.

Así el órgano electivo está integrado por cuatro parlamentarios dos senadores y dos diputados, que aseguran la participación de las dos fuerzas políticas con mayor representación parlamentaria en el nombramiento de los jueces. La Corte Suprema está representada por dos jueces y el Ejecutivo por el Presidente de la República y el Procurador General de la República que es de nombramiento presidencial. El parlamento así tiene la 
mitad de los componentes de dicho órgano que determina los miembros del Tribunal Constitucional. El sistema de nombramiento dominicano posibilita el control interorgánico en el nombramiento de jueces constitucionales, impidiendo que autoridades unipersonales nombren discrecionalmente jueces del Tribunal constitucional, como ocurre en Chile con el Presidente de la República, el que en nuestra opinión no es un buen sistema.

En siete de los diez tribunales constitucionales de latinoamérica, el Congreso Nacional o parlamento respectivo participa eligiendo magistrados: la totalidad de su miembros como en el caso de Costa Rica, Colombia, El Salvador, Perú y Venezuela; cuatro de diez en el caso de Chile (dos por el Senado y otros dos propuestos por la Cámara de Diputados por los dos tercios de sus miembros en ejercicio y ratificados por el Senado por la misma mayoría) y solo uno de cinco en el caso de Guatemala.

El Presidente de la República nombra directamente magistrados solo en dos países: tres de diez magistrados sin control ínter orgánico en Chile; uno de cinco en Consejo de Ministros en Guatemala. En el caso de Colombia el Presidente solo participa en la determinación de ternas para que el Congreso elija a tres magistrados de los nueve que integran la Corte Constitucional.

La Corte Suprema de Justicia nombra directamente tres de diez magistrados en Chile; y uno de cinco en Guatemala. En Colombia y Guatemala, la Corte Suprema solo presenta ternas a la decisión del Congreso; en el caso de Colombia presente ternas para designar tres de nueve magistrados, respecto de las cuales el Congreso decide; en el caso de Guatemala una terna para designación de uno de los cinco magistrados.

Bolivia es el único país que prevé la elección de los magistrados por elección ciudadana, la que se ha realizado recientemente en octubre de 2011 por primera vez, en cuyo proceso electoral los votos en blanco y nulos superaron los votos validamente emitidos, lo que genera un problema significativo de legitimidad y representatividad.

Los órganos que nombran magistrados en los tribunales constitucionales de Latinoamérica son, por regla general, los mismos que operan en el contexto europeo y del derecho comparado, dejando constancia de los diferentes tipos de gobierno existentes en Europa (parlamentarios y semipresidenciales) de los existentes en América del Sur (presidencialismo puros o atenuados), lo que modula en algunos casos el procedimiento de nombramiento. En todo caso, es común la participación del parlamento y del gobierno en los nombramientos de la mayor parte de los magistrados o todos los magistrados (Alemania, España, Italia, Austria, Albania, Armenia, Bélgica, Bielorrusia, Croacia, Polonia, República Checa, Chipre, Eslovaquia, Malta, Moldavia, Rumania, Rusia, entre otros) lo que los dota de legitimidad democrática indirecta $\mathrm{y}$, en algunos casos, el nombramiento 
de algunos magistrados, que es una parte minoritaria, procedente de las magistraturas superiores como ocurre en los tribunales constitucionales de diversas regiones del mundo como son Italia (cinco de quince), Bulgaria (cuatro de doce), Turquía (dos de once titulares). En Ucrania y Moldavia un tercio de los magistrados de la Corte son nombrados por el Consejo Judicial o de la Magistratura; en Espańa, dos son nombrados por el Consejo General del Poder Judicial. Constituye un caso atípico el de Bosnia-Herzegovina, donde el Presidente del Tribunal Europeo de Derechos Humanos, designa tres de los nueve magistrados que integran el Tribunal Constitucional.

Constituye una técnica adecuada y bastante extendida que los nombramientos hechos por órganos parlamentarios se realicen por mayorías calificadas o reforzadas como ocurre también en el derecho comparado en los casos de Alemania, Bélgica, España, Hungría, Italia y Portugal, entre otros países. Los quórum más usados son los de dos tercios o tres quintos, lo que obliga a buscar consensos entre las mayorías y minorías parlamentarias, ello impide que todos los magistrados pertenezcan o sean afines a la fuerza política gobernante, posibilitando la presencia de magistrados con sensibilidades jurídicas diferentes.

En nuestra opinión la presentación de candidatos por organizaciones de la sociedad civil, de universidades, colegios de abogados, entre otros cuerpos intermedios, parece un buen método para determinar un primer cuerpo de elegibles, en los cuales deberán analizarse sus antecedentes, para lo cual después puede realizarse una preselección por un cuerpo de autoridades públicas representativas, siendo de los candidatos seleccionados, donde nos parece que el Congreso Nacional por mayoría calificada de ambas ramas, debiera determinarse los jueces electos del Tribunal Constitucional. El sistema debiera tener la suficiente transparencia, como asimismo, consideración de las calificaciones e idoneidad de los candidatos, lo que debiera reflejarse objetivamente en la primera selección, aun cuando en definitiva, la elección por parte del Congreso Nacional incorpora necesariamente las consideraciones políticas, las trayectorias y las concepciones valóricas que nunca están ajenas a cualquier proceso de determinación de autoridades jurisdiccionales.

\section{3.) MAGisTRADOS SUPLENTES O ABOGADOS INTEGRANTES}

El texto constitucional de República Dominicana no hace referencia a la existencia de Magistrados suplentes del Tribunal Constitucional, lo que está regulado constitucionalmente en algunos ordenamientos constitucionales de la región. En otros casos, ello queda entregado a la ley reguladora del Tribunal Constitucional con habilitación expresa constitucional en tal sentido. 
En el caso de República Dominicana, la Ley No 137-11 Orgánica del Tribunal Constitucional dispone en su artículo 23 que en el caso de vacancia por muerte, renuncia o destitución por faltas graves en el ejercicio de su función, conforme al procedimiento de juicio político, será el Consejo Nacional de la Magistratura el que deberá proceder, en los dos meses siguientes a la vacancia, a elegir un juez en calidad de reemplazante, el cual permanecerá en el cargo hasta completar el término previsto normalmente para aquel al cual sustituyó. Ello nos señala con claridad que no hay Magistrados suplentes en el Tribunal Constitucional Dominicano.

Consideramos que una adecuada técnica jurídica en la materia es la existencia de magistrados suplentes contemplados en la norma constitucional, elegidos con los mismos requisitos y por los mismos órganos que los magistrados titulares, dotados, por tanto, de la misma legitimidad de los magistrados titulares, que pueden reemplazar a los titulares en las ocasiones determinadas específicamente por el ordenamiento jurídico. En tal sentido, nos parece conveniente el sistema implementado en Guatemala, Venezuela y Ecuador; como asimismo, parece claramente desaconsejable el sistema peruano que no contempla magistrados suplentes y que puede paralizar el sistema de jurisdicción constitucional, como ocurrió en la realidad durante el régimen fujimorista, como también es inconveniente el sistema chileno, que además es de dudosa constitucionalidad, consistente en que la Ley Orgánica del Tribunal, sin habilitación expresa de la Constitución, determina la existencia de ministros suplentes del Tribunal, seleccionados los candidatos por el mismo Tribunal Constitucional, y con nombramiento del Presidente con acuerdo del Senado.

\section{4.) LA DURACIÓN EN EL CARGO, LAS RENOVACIONES TOTALES O PARCIALES Y LA POSIBLE REELECCIÓN DE LOS MAGISTRADOS}

\subsection{1.) La duración en el cargo de los magistrados y renovación total o parcial}

La Constitución de la República Dominicana de 2010 en su artículo 187, determina que los jueces de este tribunal serán designados por un único período de nueve años. No podrán ser reelegidos, salvo los que en calidad de reemplazantes hayan ocupado el cargo por un período menor de cinco años.

La experiencia muestra la conveniencia de mandatos largos que excedan el de los órganos que concretan los nombramientos como también ocurre en Alemania, Bulgaria, España, Francia, Italia, Letonia, Lituania, Macedonia, Eslovenia, Polonia, República Checa, Rumania, Ucrania, entre otros países. La duración del mandato de nueve ańos es la fórmula más usada en el derecho comparado (Albania, Bulgaria, Eslovenia, Es- 
paña, Francia, Hungría, Italia, Lituania, Macedonia, Polonia, Rumania, Ucrania y Yugoslavia), en la República Checa y Letonia es de diez ańos, en Alemania y Rusia es de doce años, finalmente en Austria y Bélgica el mandato no tiene plazo fijo se extiende hasta el cumplimiento de setenta años de edad por los magistrados.

El período de nombramiento de los vocales, jueces o miembros de los tribunales constitucionales de Bolivia, Chile, Colombia, Costa Rica, Ecuador, El Salvador, República Dominicana y Venezuela, exceden el mandato de los órganos que realizan dichos nombramientos, lo que constituye una de las garantías que posibilitan el ejercicio independiente de presiones de los magistrados del Tribunal Constitucional por los órganos políticos representativos y eliminan las tentaciones de ser complacientes con los órganos que permitirán el nuevo mandato. La excepción en esta materia la constituyen los casos de Guatemala y Perú, donde los magistrados tienen una duración de solo cinco ańos.

Por otra parte, solo el caso chileno, ecuatoriano y salvadoreño, prevén una renovación parcial del Tribunal Constitucional; en Bolivia, Colombia, Ecuador, Guatemala, Perú y Venezuela, se contempla una renovación completa de los tribunales constitucionales, lo que puede provocar un cambio drástico y brusco de criterios jurisprudenciales.

En Costa Rica, la muerte o renuncia de un magistrado y el nombramiento del sucesor por un periodo completo hace que la renovación en la práctica de la Sala Constitucional sea parcial, en la medida en que los magistrados vayan cumpliendo su periodo constitucional.

En el caso peruano, producto de la destitución por acusación constitucional de tres magistrados del Tribunal Constitucional durante el último Gobierno de Fujimori, los cuales presentaron su caso ante la Comisión Interamericana de Derechos Humanos, la que demandó ante la Corte Interamericana, órgano que ordenó reponer a los magistrados en sus cargos, lo que se produjo solo una vez que Fujimori abandonó el gobierno, ha establecido en la práctica, una renovación parcial de los magistrados, ya que concluyeron su mandato y debieron elegirse nuevos magistrados que reemplazaron a aquellos que habían completado su periodo, mientras los magistrados que habían sido restablecidos en sus funciones permanecen en ellas hasta completar el periodo por el cual habían sido elegidos.

La renovación parcial de magistrados de los tribunales constitucionales permite que los que acceden a la función puedan aprender más rápido en contacto con los que se encuentran en funciones anteriormente, los cuales tienen la memoria institucional. Asimismo, los antiguos pueden modificar su razonamiento o enfoque metodológico en contacto con los magistrados más nuevos, lo que posibilita la renovación de enfoques y jurisprudencia del respectivo Tribunal Constitucional. 
En el Derecho Comparado hay renovación parcial de los tribunales constitucionales como ocurre en Espańa, Albania, Argelia, Bulgaria, Rumania, Senegal, entre otros países.

\subsection{2.) La existencia o no de reelección inmediata de los magistra- dos.}

Como ya hemos visto anteriormente, un párrafo del artículo 187 de la Constitución de República Dominicana, establece en principio general de la no reelección de los miembros del Tribunal Constitucional, con una regla de excepción: "No podrán ser reelegidos, salvo los que en calidad de reemplazantes hayan ocupado el cargo por un período menor de cinco años".

Nos parece conveniente, más aún, necesario, para la independencia del Tribunal y la adecuada imparcialidad de los magistrados, la regla de la no reelección para el periodo inmediatamente siguiente, sin excepciones. En tal sentido, nos parece adecuada la técnica y normativa vigente en Bolivia, Colombia, Ecuador, Perú y Venezuela ${ }^{6}$.

Esta es la regla también en el derecho comparado, como ocurre en Alemania, Albania, Andorra, Espańa, Francia, Italia, Lituania, Polonia, Portugal $^{7}$ o Rumania. En los casos de Andorra y Espańa, se puede volver a ser elegido habiendo un periodo intermedio de no integración del Tribunal Constitucional.

La reelección constituye un elemento funcional a los intereses del órgano que puede reelegirlo y condiciona psicológicamente en sus funciones al magistrado que busca mantenerse para el próximo periodo, lo que hace necesario suprimir los sistemas de reelección inmediata, estableciendo su prohibición expresamente en el texto constitucional. Nos parece claramente desaconsejable la técnica de la reelección inmediata que está constitucionalmente consagrada en el caso de Ecuador, El Salvador y Guatemala ${ }^{8}$.

6 En Bolivia, el artículo 183 al cual remite el artículo 200 de la Constitución de 2009, prohíbe la reelección de los magistrados del Tribunal Constitucional Plurinacional. En Colombia, el artículo 239 de la Constitución prohíbe expresamente la reelección de los magistrados de la Corte Constitucional. En Ecuador, el artículo 432 de la Constitución de 2008, prohíbe la reelección inmediata. En Perú, el artículo 201 de la Constitución, prohíbe la reelección inmediata de los miembros del Tribunal Constitucional. En Venezuela, el artículo 264 de la Constitución de 1999 establece que los magistrados del Tribunal Supremo de Justicia son elegidos por un periodo único de doce ańos, lo que implica una prohibición de reelección.

7 Portugal permitía la reelección inmediata de los magistrados del Tribunal Constitucional hasta la dictación de la reforma constitucional de 1998 que la prohibió.

8 En Costa Rica, el artículo 158 de la Constitución determina la reelección del magistrado de la Sala Constitucional por un nuevo periodo si al término del mismo, no es revocado por la Asamblea Legislativa por las dos terceras partes de sus miembros. En El Salvador, 
En Chile, el texto constitucional actualmente vigente prohíbe la reelección de los magistrados del Tribunal Constitucional en su artículo 92 inciso $3^{\circ}$, con la excepción de los magistrados que asumieren el cargo en reemplazo de otro por lo que resta del periodo y siempre que este no lo haya desempeñado por un periodo igual o superior a cinco años.

A su vez, un miembro del Tribunal Constitucional que cese en el cargo, debe ser reemplazado por el órgano correspondiente por el tiempo que falte al reemplazado para completar su período.

El texto constitucional dominicano asume la misma regla chilena en el artículo 187, en uno de sus párrafos: "Los jueces de este tribunal serán designados por un único período de nueve años. No podrán ser reelegidos, salvo los que en calidad de reemplazantes hayan ocupado el cargo por un período menor de cinco ańos".

\section{5.) El estatuto JuRídico de los magistrados de los TRIBU- NALES CONSTITUCIONALES}

\subsection{1.) Régimen de inhabilidades e incompatibilidades}

El régimen de inhabilidades e incompatibilidades de los miembros del Tribunal Constitucional de República Dominicana está regulado en la Ley No 137-11 de 2011, Orgánica constitucional del Tribunal Constitucional y de los Procedimientos Constitucionales.

El artículo 14 de dicha ley 137-11 determina con impedimiento para ser elegidos jueces del Tribunal Constitucional a los miembros del Poder Judicial o del Ministerio público que hayan sido destituidos por infracción disciplinaria, durante los diez años siguientes a la destitución; a los abogados que se encuentren inhabilitados para el ejercicio de la profesión por decisión irrevocable legalmente pronunciada, mientras esta dure; quienes hayan sido condenados penalmente por infracciones dolosas o intencionales, mientras dure la inhabilitación; quienes hayan sido declarados en quiebra, durante los cinco ańos siguientes a la declaratoria; quienes hayan sido destituidos en juicio político por el Senado de la República, durante los diez años siguientes a la destitución; y quienes hayan sido condenados a penas criminales.

El artículo 17 se refiere a las incompatibilidades de los Jueces del tribunal constitucional, determinando que ellos están impedidos de defender o asesorar pública o privadamente, salvo los casos excepcionales

el artículo 186 establece que los Magistrados de la Corte Suprema de Justicia, dentro de los cuales se encuentran los magistrados de la Sala Constitucional serán elegidos por la Asamblea Legislativa para un período de nueve ańos, podrán ser reelegidos y se renovarán por terceras partes cada tres ańos. En Guatemala, de acuerdo con los artículos 205 y 206 de la Constitución, los magistrados de la Corte de Constitucionalidad pueden ser reelegidos. 
previstos en el Código de Procedimiento Civil. Los integrantes del Tribunal constitucional no pueden optar a ningún cargo público electivo, ni participar en actividades político partidistas. Si concurre alguna causal de incompatibilidad de un juez nombrado, debe antes de tomar posesión, renunciar o declinar la actividad compatible, si no lo hace dentro del plazo de treinta días siguientes a su designación, se entiende que no acepta el cargo de juez para el cual fue elegido.

El artículo 16 de la Ley No 137-11 también determina que la función de juez del Tribunal Constitucional es de dedicación exclusiva, no pudiendo desarrollar ningún otro cargo público y privado y ejercer cualquier profesión u oficio.

La regla general en la materia es que la función de miembro del Tribunal Constitucional es incompatible con el ejercicio de cargos públicos o privados, administrativos o sindicales, remunerados o no; con el desempeño de funciones directivas en partidos políticos, asociaciones, fundaciones, colegios profesionales, empresas mercantiles de cualquier naturaleza; y con el ejercicio libre de la abogacía. Asimismo, en diversos ordenamientos se determina que la función de magistrado es únicamente compatible con la cátedra universitaria, la que generalmente se limita a 12 horas semanales o una cifra similar. Además, tienen las mismas incompatibilidades que los congresistas o parlamentarios y tienen prohibido en ciertos ordenamientos regulatorios, afiliarse a organizaciones políticas. Puede sostenerse que el estatuto jurídico del juez constitucional dominicano es de los más rigurosos en el derecho comparado latinoamericano.

(2.5.2.) Las causales de cesación en el cargo de los magistrados que integran los tribunales constitucionales.

La regulación constitucional dominicana en su artículo 186 determina que los miembros del Tribunal Constitucional son "inamovibles durante el tiempo de su mandato. La condición de juez solo se pierde por muerte, renuncia o destitución por faltas graves en el ejercicio de sus funciones, en cuyo caso se podrá designar una persona para completar el periodo".

En algunos ordenamientos constitucionales se establece la causal de destitución por acusación constitucional o juicio político, lo que se establece generalmente en los ordenamientos en que el Tribunal o Corte Constitucional es parte del Poder Judicial (El Salvador, Guatemala; Venezuela), pero también está contemplado en ordenamientos constitucionales en que el Tribunal constitucional es un órgano extra poder (Perú), a esta última perspectiva, se suma ahora el caso de los jueces del Tribunal constitucional de República Dominicana.

En efecto, el artículo 22 de la Ley No 137-11, en su literal c) determina la destitución por la comisión de faltas graves en el ejercicio de sus funciones, conforme al procedimiento de juicio político establecido en la Constitución de la República. La normativa deja en evidencia el carácter 
de norma legal con una causal genérica e indeterminada, que posibilita un uso discrecional por parte del parlamento.

La posibilidad de que los jueces del Tribunal Constitucional puedan ser objeto de un juicio político o acusación constitucional en mi consideración constituye un riesgo grave para la independencia e imparcialidad de los jueces constitucionales en el desempeńo de sus funciones jurisdiccionales. La historia reciente de América del Sur en la materia no alienta este tipo de soluciones, el caso de los jueces del Tribunal Constitucional destituidos bajo el régimen fujimorista y restituidos en funciones por parte de una sentencia de la Corte Interamericana de Derechos Humanos; el criticable sistema de plantear un juicio político y dejarlo pendiente por años, como ocurrió en el caso de Ecuador a partir de 2003; la amenaza de juicio contra los jueces del ex Tribunal Constitucional de Bolivia en 2008, son casos señeros en la perspectiva de la búsqueda de domesticación del Tribunal Constitucional por el gobierno de turno.

Consideramos mas adecuado que los magistrados del Tribunal Constitucional no sean susceptibles de ser acusados constitucionalmente, sino solamente puedan ser objeto de imputación y condena en el caso de cometer delitos, debiendo ser enjuiciados por un tribunal de justicia independiente e imparcial, luego de un debido proceso, por delitos claramente tipificados en el ordenamiento jurídico.

Esta perspectiva exige una cuidadosa selección de los magistrados del Tribunal Constitucional por los órganos constitucionales que los eligen y nombran.

Por regla general se establece la vacancia o la pérdida del mandato por la renuncia; la muerte; la incapacidad física o mental sobrevenida, legalmente comprobada; las incompatibilidades sobrevinientes; y la condena por sentencia ejecutoriada.

\section{6.) EL PROCEDIMIENTO DE NOMBRAMIENTO DEL PRESIDENTE DEL TRIBUNAL CONSTITUCIONAL Y SU PERIODO DE EJERCICIO EN EL CARGO}

El Presidente del Tribunal Constitucional de República Dominicana, de acuerdo al artículo 12 de la Ley No 137-11, es nombrado por el Consejo Nacional de la magistratura, el cual elegirá también un primer y segundo sustituto, en caso de cesación temporal del Presidente en el cargo.

Dicha norma constituye una excepción en el derecho comparado latinoamericano, ya que las normas que regulan la elección del Presidente de los respectivos tribunales constitucionales latinoamericanos son similares en los diversos países, otorgando a los respectivos jueces integrantes de los tribunales la determinación de su Presidente, lo que dota al Tribunal de una adecuada autonomía en el ejercicio de sus funciones y una plena 
autoadministración interna. La mayoría del los Tribunales sudamericanos prevén el ejercicio de la presidencia por un periodo de dos ańos (Chile, Ecuador y Perú), el periodo se reduce a un año en Colombia y se amplía a cinco años en Bolivia. El sistema colombiano permite que todos los magistrados sean presidentes de la Corte Constitucional un año durante su periodo de magistrado.

\section{7.) LOS VOTOS CONCURRENTES Y DISIDENTES EN LAS SENTENCIAS DE LOS TRIBUNALES CONSTITUCIONALES}

En la Constitución de la República Dominicana de 2010, en su artículo 186, se precisa que "Los jueces que hayan emitido un voto disidente podrán hacer valer sus motivaciones en la decisión adoptada".

En la mayoría de las legislaciones nacionales se establece que las sentencias de los respectivos tribunales constitucionales deben ser publicadas con los votos concurrentes o disidentes o particulares, si los hubiere, tanto en lo que dice relación con los fundamentos y la decisión.

Los votos particulares disidentes posibilitan a los jueces o magistrados constitucionales expresar públicamente sus desacuerdos sobre el contenido y la argumentación de la sentencia sostenida por el voto mayoritario, y los votos concurrentes las diferencias de razonamiento o argumentación en el sostenimiento de la sentencia compartida.

Los detractores de los votos minoritarios señalan que ellos debilitan la sentencia y la presentan como la confrontación de razonamientos jurídicos con un resultado aritmético, por tanto, relativo y provisional, lo que se vería como una situación que resta autoridad a la sentencia del Tribunal.

En nuestra opinión, los votos concurrentes y los votos disidentes o de minoría, constituyen un elemento para analizar la consistencia y fundamento de las sentencias por parte de la comunidad jurídica que tiene como tarea la crítica de la calidad y fundamento los fallos de la jurisdicción constitucional. Su existencia incentiva a los magistrados a encontrar puntos de consenso, como asimismo posibilita que los magistrados hagan un esfuerzo adicional de argumentación jurídica para convencer de la corrección de sus posiciones, lo que, además, produce un efecto pedagógico sobre la ciudadanía. Nos manifestamos claramente partidarios de la existencia de votos de minoría, lo que posibilita también comprender que la sentencia se construye en la confrontación de razones jurídicas y su debate, posibilitando además el control ciudadano y la crítica de la comunidad jurídica.

En el contexto europeo, los votos particulares están consagrados en los tribunales constitucionales de Bulgaria, Croacia, Espańa, Eslovenia, Polonia, Rusia, y desde 1970, Alemania, que no lo tenía contemplado 
originalmente. Es necesario precisar que, en los países en que no se regulan los votos minoritarios, entre ellos, Francia e Italia, se produce lo que Cappelletti denomina confesiones razonadas, que no son otra cosa que las entrevistas o artículos desarrollados por los magistrados constitucionales para expresar sus puntos de vista sobre las sentencias.

\section{3) ANÁlisis de COMPETENCIAS DEL Tribunal Constitucional DOMINICANO}

Las competencias de los tribunales constitucionales por regla general se clasifican en:

1.- Control de constitucionalidad normativa u orgánica.

2.- Control de constitucionalidad de conflictos de atribuciones o competencias.

3.- Control de constitucionalidad a través del amparo de derechos fundamentales y sus garantías.

4.- Otras competencias residuales.

\section{1.) EL CONTROL DE CONSTITUCIONALIDAD SOBRE NORMAS O PRE- CEPTOS JURÍDICOS SE DESARROLLA POR TODOS LOS TRIBUNA- LES CONSTITUCIONALES CON DIVERSAS MATIZACIONES}

\subsection{1.) El control de constitucionalidad sobre normas jurídicas de carácter preventivo}

El control preventivo de constitucionalidad tiene por objeto evitar ya sea el nacimiento de normas jurídicas contrarias a la Constitución o impedir que normas provenientes del Derecho Internacional inconstitucionales se incorporen al ordenamiento jurídico nacional. Se trata de un control de prevención, por lo que la acción, requerimiento o consulta tiene como efecto impedir que continúe el procedimiento de aprobación o incorporación de la norma jurídica cuestionada mientras se pronuncia el Tribunal o Corte Constitucional, estableciendo la compatibilidad o incompatibilidad de la norma con la Constitución. Dicha decisión es jurídica, constituyendo una sentencia de carácter vinculante, lo que significa que los órganos estatales deben acatarla y cumplirla.

Dicho control preventivo de constitucionalidad puede ser amplio o restringido.

El control preventivo será amplio cuando verse sobre reformas constitucionales, tratados internacionales y los diversos tipos de proyectos de leyes y resoluciones administrativas, como ocurre en Bolivia y Colombia. 
Como sobre reformas constitucionales, proyectos de ley y decretos supremos representados por la Contraloría General de la República, en el caso chileno.

El control preventivo será restringido cuando queden excluidas del control las reformas constitucionales y este se refiera solamente a tratados internacionales y proyectos de ley como ocurre en Ecuador y Venezuela o solamente a tratados internacionales como en el caso de República Dominicana.

\subsection{2.) El control preventivo de constitucionalidad de los tratados o convenciones internacionales}

El Tribunal Constitucional dominicano, de acuerdo al artículo 185, numeral 2), establece "el control preventivo de los tratados internacionales antes de su ratificación por el órgano legislativo". La norma constitucional se complementa con los artículos 55 y siguientes de la Ley No 137-11, la que determina por la redacción del artículo 55, que este es un control preventivo obligatorio, la norma establece que el Presidente de la República someterá los tratados internacionales suscritos al Tribunal Constitucional, a fin de que este ejerza sobre ellos el control previo de constitucionalidad". El Tribunal deber decidir sobre la materia dentro de los treinta días siguientes a su recibo, indicando cuando corresponda los aspectos en los cuales recae la inconstitucionalidad y las razones en que fundamenta su decisión, conforme al artículo 56 de la Ley. La decisión del Tribunal Constitucional es vinculante para el Congreso Nacional y el Poder Ejecutivo.

El control preventivo obligatorio de los tratados internacionales parece más coherente con las obligaciones derivadas de la Convención de Viena sobre Derecho de los Tratados de 1969, en sus artículos 26, 27 y 31 , que obligan a cumplir los tratados libre y voluntariamente ratificados, de buena fe, sin oponer el Derecho interno como obstáculo al cumplimiento de las obligaciones internacionales, lo contrario implica una desvalorización de la seguridad jurídica, una afectación eventual del honor del Estado y la responsabilidad internacional del mismo, cuando se realiza un control reparador de los mismos.

De los procedimientos de control de constitucionalidad de tratados, los que se adecuan de mejor forma a una perspectiva armónica del Derecho Interno y Derecho Internacional, como asimismo, al cumplimiento de buena fe de las obligaciones válidamente contraídas por los Estados, sin oponer a ellos obstáculos de derecho interno que son expresión del propio poder estatal son, sin duda, los establecidos en las Constituciones de Bolivia, Colombia, Ecuador y ahora de República Dominicana por ser un control preventivo obligatorio respecto de todos los tratados interna- 
cionales, control que impide que se produzcan conflictos entre derecho interno y Derecho Internacional.

Consideramos que un tratado o convención internacional ratificado y con las comunicaciones de ratificación canjeadas o cumpliendo las disposiciones de los artículos 11 y 24 de la Convención de Viena sobre Derecho de los Tratados, desarrollado por los órganos competentes, sin que exista un reparo previo de constitucionalidad, habiéndose integrado el tratado o convención al ordenamiento jurídico interno, es adecuado considerar la inexistencia de control represivo de constitucionalidad, por razones de seguridad jurídica, de respeto a los actos propios, de respeto al honor del Estado, de cumplimiento de los compromisos internacionales, quedando solamente como alternativa legítima y viable la denuncia de la Convención o tratado de acuerdo con las reglas del Derecho Internacional?.

El control preventivo de constitucionalidad de los tratados internacionales está previsto como competencia de los tribunales constitucionales de Bolivia, Colombia, Chile y Ecuador, como asimismo de la Sala Constitucional del Tribunal Supremo de Justicia de Venezuela.

\subsection{3.) El control represivo o correctivo de constitucionalidad de normas jurídicas por los tribunales constitucionales}

El control represivo, correctivo o a posteriori se concreta cuando la norma impugnada ya forma parte del ordenamiento jurídico, pudiendo adoptar distintas modalidades y vías.

\subsubsection{1.) Inconstitucionalidad de forma y de fondo}

Una norma jurídica puede ser contraria a la Constitución en la forma o en el fondo.

La inconstitucionalidad de forma se produce cuando la norma se elabora por una autoridad diferente de la que está determinada constitucionalmente, o cuando la autoridad competente para establecer la norma en el procedimiento de su elaboración, aprobación, promulgación o publicación no se realizó de acuerdo al procedimiento contemplado en la Constitución.

La inconstitucionalidad de fondo se establece cuando la norma impugnada, elaborada por la autoridad u órganos competentes y de acuerdo al

9 Sobre la materia ver el interesante trabajo de BAZÁn, Víctor. (2003). Jurisdicción constitucional y control de constitucionalidad de los tratados internacionales. Un análisis de derecho comparado. México: Editorial Porrúa.120 pp. 
procedimiento previsto en la Constitución, entra en colisión con la Carta Fundamental ya que contiene una infracción, incompatibilidad o desconocimiento de los valores, principios y reglas substantivas de la Constitución.

\subsubsection{2.) Inconstitucionalidad sobreviniente}

Es la hipótesis en que una norma jurídica inicialmente constitucional en la forma y el fondo deviene en inconstitucional producto de una reforma constitucional, en la medida que sus enunciados contradicen los valores, principios o reglas substantivas introducidas a la Constitución por obra del constituyente instituido o derivado o por el establecimiento de una nueva Carta Fundamental. En este caso, nada impide que pese a que dicha norma haya sido previamente considerada constitucional por el órgano de control de constitucionalidad respectivo, pueda ser sometida a un nuevo control de constitucionalidad, sin que pueda oponerse a ello la cosa juzgada del fallo anterior.

\subsubsection{3.) Inconstitucionalidad por omisión}

Solo en Venezuela, dentro de los países con tribunales constitucionales de América del Sur, se contempla expresamente en la Carta Fundamental el control de constitucionalidad de las omisiones legislativas, teniendo como antecedentes el Tribunal Constitucional de Portugal (art. 283 de la Constitución) y el control de omisiones legislativas en Brasil (art. $103 \mathrm{No} 2$ de la Constitución), lo que no significa que los tribunales constitucionales de la región no realicen este tipo de control. En América Central el control por omisiones inconstitucionales está regulado también en Costa Rica.

La inconstitucionalidad por omisión tiene dos variantes básicas: la inconstitucionalidad por retardo y la inconstitucionalidad por negación.

La inconstitucionalidad por retardo o mora, resulta de la inercia de la autoridad para establecer la norma legal o general respectiva. El caso más conocido y frecuente es el retardo del legislador para dictar las leyes de desarrollo constitucional para organizar y regular poderes públicos u órganos constitucionales o para desarrollar y regular cláusulas que no tienen carácter autoejecutivas de la Carta Fundamental.

La inconstitucionalidad por negación o por omisión relativa, existe cuando el órgano estatal no efectiviza el mandato constitucional, por ejemplo, cuando el legislador sanciona la ley, pero lo hace incorrectamente, no regulando algunas hipótesis que debe considerar o dejando lagunas en la legislación, excluyendo a un grupo del ejercicio de un derecho o negándole arbitrariamente la protección de sus intereses. 


\subsubsection{4.) Control abstracto o concreto}

El control represivo, reparador o correctivo de constitucionalidad sobre normas jurídicas puede tener un carácter abstracto o concreto, encontrándose ambas modalidades o solo una de ellas en los tribunales constitucionales de Latinoamérica, lo que depende del modelo de control de constitucionalidad desarrollado sobre normas legales.

En la materia hay diversas modalidades en Latinoamérica. En efecto, hay modelos de control de constitucionalidad mixto, estableciéndose un control judicial difuso en los tribunales ordinarios y un control concentrado en el Tribunal Constitucional como ocurre en Colombia, Ecuador y Venezuela, como asimismo en República Dominicana; un modelo dual $o$ paralelo, cuando coexisten el control difuso concreto en manos de la justicia ordinaria y el control concentrado abstracto en el Tribunal Constitucional, sin mezclarse ni desnaturalizarle, actuando en forma paralela, lo que ocurre en el caso del Perú, o un control concentrado únicamente en el Tribunal Constitucional como ocurre en Bolivia y Chile, para señalar algunos ejemplos.

El artículo 185 No 1) de la Constitución Dominicana prevé dentro de las competencias del Tribunal Constitucional "Las acciones directas de inconstitucionalidad contra las leyes, decretos, reglamentos, resoluciones y ordenanzas, a instancia del Presidente de la República, de una tercera parte de los miembros del Senado o de la Cámara de Diputados y de cualquier persona con interés legitimo y jurídicamente protegido". La ley 137-11 Orgánica Constitucional del Tribunal Constitucional determina en su artículo 37 que esta acción directa puede ser interpuesta, a instancias del Presidente de la República, de una tercera parte de los miembros del Senado o de la Cámara de Diputados y de cualquier persona con un interés legítimo y jurídicamente protegido. Las acciones de inconstitucionalidad acogidas producen cosa juzgada y eliminan la norma o acto del ordenamiento jurídico, eliminación que rige a partir de la publicación de la sentencia, según determina el artículo 45 de la ley.

Ello se complementa con un control difuso en manos de los tribunales ordinarios de acuerdo al artículo 188 de la Constitución: "Los tribunales de la República conocerán la excepción de constitucionalidad en los asuntos sometidos a su conocimiento".

Ello permite sostener la existencia de un modelo mixto de control de constitucionalidad: un control reparador abstracto en manos del Tribunal Constitucional y un control reparador difuso con efectos inter partes en manos de los tribunales ordinarios. 


\section{2.) El Control de CONSTitucionalidad DE CONFlictos DE ATRIBUCIONES O DE COMPETENCIAS}

En efecto, todo conflicto entre órganos constitucionales constituye un conflicto constitucional, que pone en jaque el sistema con el que la Constitución organiza la distribución de funciones y competencias. Los tribunales o Cortes Constitucionales son, sin lugar a dudas, los órganos más idóneos para asumir la resolución de estos conflictos o contiendas de atribuciones o de competencias entre órganos del poder público, en virtud de ser guardianes de la preservación de la repartición de competencias y del equilibrio orgánico establecido por la Constitución, como asimismo, intérprete supremo de la Constitución, siendo el órgano jurídico técnico que cuenta con mayor legitimidad para ello.

Estos conflictos de competencias o atribuciones entre órganos estatales, regionales o locales pueden ser conflictos positivos o negativos. El conflicto positivo es aquel que es producto de una determinada actuación de un órgano que se atribuye una competencia que otro órgano entiende que le pertenece, presentándose así un conflicto entre dos órganos que consideran que son los legitimados para adoptar el acto o resolución, siendo el órgano requirente el que se considere privado del ejercicio de su competencia o atribución. Por otra parte, es posible también la existencia de un conflicto negativo producto de la pasividad de un órgano cuya inactividad impide el ejercicio normal de las competencias de otro órgano, los cuales también pueden ser conocidos y resueltos por el Tribunal Constitucional por el procedimiento previsto para las hipótesis de indebida asunción de atribuciones, donde el órgano requirente será aquel que se considera impedido de ejercer su competencia por la inactividad del órgano requerido.

En estos casos estamos en un proceso inter partes, donde el Tribunal Constitucional determina definitivamente a qué órgano corresponde la titularidad de la competencia o atribución controvertida. La finalidad de acudir al Tribunal Constitucional es la de precisar la titularidad de la competencia o atribución, como asimismo, en su caso, anular las normas, resoluciones o actos viciados de incompetencia que haya generado el conflicto.

Para que exista un conflicto o contienda de competencia es necesario que los sujetos involucrados cuenten con legitimidad para plantear la acción, los cuales son, por regla general los órganos constitucionales, los gobiernos regionales, departamentales o locales. Asimismo, es necesario que el conflicto verse sobre una dimensión constitucional, en la medida que se trate de competencias o atribuciones que gocen de reconocimiento en la Carta Fundamental o sean parte del bloque constitucional, al que se integran, en ciertos casos, los contenidos de leyes orgánicas constitucio- 
nales referentes a la materia. Es necesario precisar que esas competencias pueden ser exclusivas, concurrentes o compartidas, como asimismo pueden ser delegadas.

Lo que se busca a través de este tipo de proceso constitucional es que los órganos respeten el orden de competencias y atribuciones determinado por la Constitución y la normativa que pudiere integrar el bloque de constitucionalidad, como asimismo, pronunciarse sobre una eventual norma, resolución o acto, emitido por un órgano sin competencia para ello.

Es necesario observar que los conceptos y vocablos conflicto de competencia o conflicto de atribuciones no son utilizadas, en América del Sur, siempre con un mismo sentido o alcance. En efecto, en el caso del Perú, se utiliza los vocablos "conflicto de competencia" cuando el conflicto se produce entre gobiernos locales (municipales) o regionales, de acuerdo con los artículos 191, 192 y 197 de la Carta Fundamental, mientras se utiliza "conflicto de atribuciones" cuando se refiere a "las posibilidades jurídicas de actuar que la Constitución y las normas que las desarrollan, confieren a los poderes y órganos constitucionales del Estado". A su vez, Bolivia y Venezuela se refieren a "controversias" entre poderes públicos u órganos estatales, regionales o locales. En Chile, se utiliza las expresiones "contienda de competencias" y en República Dominicana, "conflictos de competencia”.

La Constitución Dominicana en su artículo 185 No 3) determina como competencia del Tribunal constitucional dominicano resolver "Los conflictos de competencia entre los poderes públicos, a instancia de uno de sus titulares".

Los tribunales constitucionales de Bolivia, Chile, Ecuador Perú y República Dominicana, como asimismo, la Sala Constitucional del Tribunal Supremo de Venezuela tienen dentro de sus funciones la resolución de conflictos de competencia entre diversos órganos del Estado, con mayor o menor amplitud ${ }^{10}$, competencias de las cuales carece en la actualidad la Corte Constitucional de Colombia.

10 En el caso de Bolivia, el artículo 120 No 2 de la Constitución, le entrega al Tribunal Constitucional la atribución de conocer y resolver los conflictos de competencia y controversias entre los Poderes Públicos, la Corte Nacional Electoral, los departamentos y los municipios, los cuales se regulan en los artículos 71 a 75 de la ley $\mathrm{N}^{\circ} 1.836$ del Tribunal Constitucional de 1998.

En el caso de Chile, las contiendas de competencias entre órganos políticos o administrativos y tribunales de justicia son resueltos por el Senado, de acuerdo a lo dispuesto en el artículo 49 No 3 de la Constitución, o por la Corte Suprema de Justicia, de acuerdo a lo previsto en el artículo 79 inciso final de la Carta Fundamental. El proyecto de reforma constitucional en actual tramitación en el Congreso Nacional, atribuye al Tribunal Constitucional las potestades en materia de contiendas de competencias que actualmente tiene el Senado y la Corte Suprema de Justicia de acuerdo a los artículos 49 No 3 y 79 inciso final de la Constitución. 


\section{3.) El AMPARO DE DERECHOS ANTE loS TRIBUNALES CONSTITU- CIONALES}

En la Constitución Dominicana de 2010, en su artículo 184, al precisar las funciones del Tribunal Constitucional se determina que "Habrá un Tribunal Constitucional para garantizar la supremacía de la Constitución, la defensa del orden constitucional y la protección de los derechos fundamentales".

En el caso del Ecuador, el artículo 276 No 6 determina, entre las atribuciones del Tribunal Constitucional, conocer y dirimir los conflictos de competencia o atribuciones asignadas por la Constitución que se produce entre órganos que no tienen un superior jerárquico común, como son los que se susciten entre el Presidente de la República, el Congreso Nacional, la Corte Suprema de Justicia y las corporaciones provinciales o municipales, correspondiendo la facultad de solicitar la resolución el órgano o entidad que reclama la competencia. Como expresa Morales Tobar, lo seńalado no implica que la contienda de competencia se produzca exclusivamente entre los órganos antes indicados, ya que el inciso tercero del artículo 277 se limita a seńalar la legitimación de los órganos para solicitar la dirimencia del conflicto de competencia. "La contienda se puede producir entre cualquiera de los órganos seńalados en esta disposición constitucional frente a otros órganos, cuyas facultades se encuentren previstas en el texto constitucional, correspondiendo solicitar la dirimencia al órgano que la reclama o impugna de otro, en caso de competencia positivo o negativo, respectivamente".

En el caso del Perú, el artículo 202 No 3 de la Constitución, seńala que corresponde al Tribunal Constitucional conocer, los conflictos de competencia o atribuciones asignadas por la Constitución, conforme a la ley No 26.435 orgánica del Tribunal Constitucional, regula esta materia en su título IV, en su artículo 46, precisa que el Tribunal conoce de los conflictos sobre competencias o atribuciones asignadas directamente por la Constitución o las leyes orgánicas que delimiten los ámbitos propios de los poderes del Estado, los órganos constitucionales, los gobiernos regionales o municipales y que opongan al Poder Ejecutivo con uno o más gobiernos regionales o municipalidades; a dos o más gobiernos regionales, municipalidades; o de ellos entre sí; a los poderes del Estado entre sí o con cualquiera de los otros órganos constitucionales, o de estos entre sí.

El artículo 47 de la ley No 26.435 determina que el conflicto se produce cuando algunos de los poderes o entidades estatales "adopta decisiones o rehúye deliberadamente actuaciones, afectando competencias o atribuciones que la Constitución y las leyes orgánicas confieren a otro".

En el caso de Venezuela, de acuerdo al artículo 336 No 9, le corresponde a la Sala Constitucional del Tribunal Supremo de Justicia resolver las controversias constitucionales que se susciten entre cualesquiera de los órganos del Poder Público. Esta competencia como señala Brewer-Carías, se refiere a los conflictos respecto de atribuciones constitucionales, y corresponde a los conflictos entre los "Órganos del Poder Público, tanto en su distribución vertical (República, Estados y Municipios), como en su división horizontal a nivel nacional (Poder Legislativo, poder Ejecutivo, Poder Judicial, Poder Ciudadano, Poder Electoral) y a nivel estadal y municipal (Poder Legislativo y Poder Ejecutivo)". Se trata de controversias sobre atribuciones constitucionales entre los órganos que ejercen el poder público, las cuales deben diferenciarse de las controversias administrativas que pueden suscitarse entre la República, los estados, los municipios u otros entes públicos, los que deben ser resueltos por la Sala Político-Administrativa del Tribunal Supremo de Justicia, de acuerdo con el artículo 266 No 4 de la Constitución, como jurisdicción contencioso administrativa. 
A su vez, el artículo 186 que se refiere a las competencias del Tribunal Constitucional, no fija el amparo de derechos como atribución del Tribunal Constitucional, sin embargo, este puede establecerse por ley, ya que el numeral $4^{\circ}$ del mismo artículo entrega al legislador la potestad de establecer nuevas atribuciones que pueda ejercer el Tribunal Constitucional: "4) Cualquier otra materia que disponga la ley".

En la Ley No 137-11 Orgánica constitucional del Tribunal Constitucional del presente ańo, en efecto, el Tribunal Constitucional, de acuerdo al artículo 53 de la Constitución, tiene la potestad de revisar las decisiones jurisdiccionales que hayan adquirido la autoridad de cosa irrevocablemente juzgada, con posterioridad al 26 de enero de 2010 , fecha de proclamación y entrada en vigencia de la Constitución. Esta perspectiva contempla como hipótesis, en su numeral 3, cuando se haya producido una violación de un derecho fundamental, siempre que concurran y se cumplan todos y cada uno de los siguientes requisitos:

a) Que el derecho fundamental vulnerado se haya invocado formalmente en el proceso, tan pronto quien invoque la violación haya tomado conocimiento de la misma;

b) Que se hayan agotado todos los recursos disponibles dentro de la vía jurisdiccional correspondiente y que la violación no haya sido subsanada; $y$

c) Que la violación al derecho fundamental sea imputable de modo inmediato y directo a una acción u omisión del órgano jurisdiccional, con independencia de los hechos que dieron lugar al proceso en que dicha violación de produjo, los cuales el Tribunal Constitucional no podrá revisar.

La disposición legal agrega que la revisión por la causa prevista en este numeral $3^{\circ}$ de este artículo solo será admisible por el Tribunal Constitucional cuando este considere que, en razón de su especial trascendencia o relevancia constitucional, el contenido del recurso de revisión justifique un examen y una decisión sobre el asunto planteado. El tribunal siempre debe motivar su decisión.

A su vez, la ley No 137-11, en su artículo 94, determina que todas las sentencias emitidas por el juez de amparo pueden ser recurridas en revisión ante el Tribunal Constitucional en la forma y bajo las condiciones establecidas en esta ley. La resolución que concede el amparo, de acuerdo al artículo 91 de la ley comentada, se limitará a prescribir las medidas necesarias para la pronta y completa restauración del derecho fundamental conculcado al reclamante o para hacer cesar la amenaza a su pleno goce y ejercicio. Finalmente, el artículo 93 de la ley otorga competencia al juez 
que estatuya en materia de amparo para pronunciar astreintes, con el objeto de constreńir al agraviante al efectivo cumplimiento de lo ordenado.

El amparo de derechos constituye una acción tutelar de derechos humanos o fundamentales, los cuales son protegidos frente a decisiones, actos $\mathrm{u}$ omisiones ilegales o arbitrarios de terceros, sean estos particulares, órganos o autoridades del Estado. A diferencia de las acciones de inconstitucionalidad en que se analiza la compatibilidad de la norma jurídica en abstracto determinando su compatibilidad con el marco normativo constitucional, en materia de amparo de derechos nos encontramos ante un control constitucional concreto que protege intereses subjetivos.

En Bolivia, Colombia, Costa Rica, Ecuador, Perú y Venezuela ninguna autoridad o funcionario público se sustrae al alcance del amparo o tutela de derechos fundamentales, ni aun las resoluciones de los tribunales ordinarios cuando ellas vulneran derechos fundamentales. A esta perspectiva se suma, con algunos matices, el nuevo Tribunal Constitucional de República Dominicana.

Así, puede sostenerse que no hay cosa juzgada de las sentencias de los tribunales ordinarios mientras no se haya agotado el plazo y procedimiento de amparo ante el Tribunal o Corte Constitucional, decisión jurisdiccional esta última que busca restablecer el imperio del derecho afectado, preservando $\mathrm{u}$ otorgando fuerza normativa al derecho constitucional material, superando los déficit de derechos fundamentales, los déficit de interpretación y ponderación de derechos o los déficit de procedimiento.

El Tribunal Constitucional chileno es el único que se sustrae de esta concepción de Constitución y de control de constitucionalidad fuerte, la que comprende la garantía efectiva de los derechos fundamentales de la persona humana. En este caso el amparo de derechos está radicado en las Cortes de Apelaciones como tribunal de primera instancia y la Corte $\mathrm{Su}$ prema como tribunal de apelación.

El déficit de derechos fundamentales se produce cuando en la resolución de un caso, el tribunal ordinario competente ha ignorado un derecho humano o fundamental aplicable, anulando la resolución o sentencia del tribunal ordinario respectivo.

El déficit de interpretación ocurre cuando la resolución o sentencia judicial ha aplicado el derecho fundamental pero ha interpretado erróneamente su significado o alcance constitucional. El Tribunal o Corte Constitucional, en tal caso, verifica el uso correcto de las reglas de interpretación constitucional o la adecuada delimitación y alcance del derecho en cuestión.

El déficit de ponderación se refiere a la inadecuada determinación de los límites de los derechos en caso de tensión entre dos o más de ellos, afectándose el contenido de ellos más allá de lo que autoriza la Constitución material y formal. 
El déficit de procedimiento se produce cuando el procedimiento judicial de los tribunales ordinarios no respetan el derecho de acceso a la jurisdicción o las reglas del debido proceso (tribunal independiente e imparcial, adecuado emplazamiento, asistencia de letrado adecuada y eficaz, suficiente y adecuada prueba en el proceso, sentencia sin dilaciones indebidas, sentencia motivada, congruente y en una consideración adecuada de las fuentes del derecho, revisión por otro tribunal igualmente independiente e imparcial, reformatio en peius) o cuando actúan más allá del ámbito competencial otorgado por la Constitución y las leyes dictadas conforme a ella.

\subsection{1.) Algunas consideraciones finales sobre el amparo de derechos}

Así, a través de diversas fórmulas y técnicas jurídicas los tribunales constitucionales realizan una unificación de la jurisprudencia en materia de protección de los derechos fundamentales, más amplia o más restringida, aplicándose siempre como mínimo a la acción o recurso de amparo o tutela de derechos fundamentales.

En el caso ecuatoriano la protección de tales derechos se remite no solo a los derechos constitucionales sino también a los derechos y garantías asegurados por los tratados de derechos humanos ratificados por el Estado, lo que parece más conforme con la obligación de los Estados Partes de la Convención Americana de Derechos Humanos, cuyo artículo 25 establece la obligación de amparar a través de un procedimiento breve, sencillo y eficaz todos los derechos consignados en la Constitución, la Convención y las leyes del Estado Parte.

A su vez, nos parece como procedimiento más adecuado el previsto para la Corte Constitucional de Colombia, que tiene la competencia de revisar discrecionalmente las sentencias de tutela de derechos de los tribunales ordinarios, respecto de la correcta consideración, interpretación y ponderación de derechos, unificando la jurisprudencia y dando seguridad jurídica de la aplicación de los derechos. Finalmente, el procedimiento seguido por la Corte Constitucional colombiana de conocimiento y resolución de salas compuesta de tres magistrados, siendo cada magistrado presidente de una sala compuesta por otros dos magistrados que le siguen en orden alfabético de apellidos, permite conocer y resolver, simultáneamente, una gran cantidad de casos, todo ello unido al mantenimiento de una línea jurisprudencial que es resorte del pleno de la Corte.

Chile es el único país con Tribunal Constitucional de América del Sur, el cual no tiene competencia en materia de amparo de derechos humanos o fundamentales, debilitando la fuerza normativa de la Constitución en materia de derechos esenciales y su interpretación unificadora, no 
existiendo un parámetro único y seguro en la aplicación de los derechos humanos o fundamentales.

\section{4) LA SENTENCIA CONSTITUCIONAL}

Como recordaba Raúl Bocanegra, "la decisión sobre la naturaleza y el alcance de la vinculación de las decisiones constitucionales no supone otra cosa, en la práctica, que decidir, en una medida enormemente significativa, sobre la distribución de poderes entre los más altos órganos constitucionales, y decidir, en consecuencia, sobre un elemento esencial de la estructura constitucional, en cuanto que un grado mayor o menor de fijación o de vinculatoriedad de las resoluciones de un Tribunal de esta naturaleza -y frente a lo que ocurre en el proceso ordinario- despliega efectos cuya trascendencia vital sobre los demás órganos constitucionales y sobre la propia Constitución fácilmente se alcanza" ${ }^{11}$.

El tema nos pone en un plano de derecho constitucional material, en que se deciden los valores que son prioritarios, el grado relativo de seguridad jurídica o de apertura a la revisión, como asimismo la fuerza vinculante de la interpretación constitucional hecha por el Tribunal Constitucional.

No debemos olvidar que la tarea de un Tribunal Constitucional además de la resolución de un conflicto coyuntural o concreto, es la de establecer criterios pacificadores hacia el futuro e impedir la sucesiva repetición de controversias, dotando de protección a la Carta Fundamental, a través de una adecuada interpretación de ella.

El derecho procesal constitucional es un derecho procesal de un tipo especial, el cual se resiste a recibir principios y desarrollos procedimentales concretos del procedimiento general, ellos necesariamente deben pasar por el colador del derecho constitucional material, dotando al proceso constitucional de categorías jurídico-procesales diferentes.

\section{1.) DISTINCIONES ENTRE COSA JUZGADA CONSTITUCIONAL, EFEC- TOS DE LA SENTENCIA Y FUERZA VINCULANTE DE LA SENTENCIA}

La cosa juzgada constitucional se refiere a la incompetencia de la Corte o Tribunal Constitucional para "conocer de nuevo de un cargo de

11 Bocanegra Sierra, Raúl. (1981). "Cosa juzgada, vinculación, fuerza de ley de las decisiones del Tribunal Constitucional alemán”, en Revista Española de Derecho Constitucional, Volumen $1 N^{\circ} 1$. Madrid: Centro de Estudios Constitucionales, p. 238. 
inconstitucionalidad contra una norma, ya decidido favorable o desfavorablemente por ella"12.

Los efectos de la sentencia constitucional se refieren a la modificación en el ordenamiento jurídico producto de la nulidad (expulsión de la norma jurídica inconstitucional del ordenamiento) y en las situaciones de los destinatarios que produce la parte resolutiva de las sentencias que determina la inconstitucionalidad y nulidad del precepto jurídico hasta entones eficaz (efectos erga omnes o inter partes y efectos ex nunc o ex tunc).

La fuerza vinculante de la sentencia del Tribunal Constitucional es una cosa distinta de la cosa juzgada constitucional. Ella se refiere a la fuerza horizontal y vertical que despliega esencialmente la parte motiva o considerativa del fallo en que se establecen los principios y fundamentos inescindibles de la parte resolutiva, donde se encuentra la ratio decidendi del fallo del Tribunal Constitucional.

\subsection{1.) La cosa juzgada constitucional}

En los países que tienen una jurisdicción constitucional concentrada de normas jurídicas infraconstitucionales, la sentencia del Tribunal o Corte Constitucional adopta el carácter de cosa juzgada formal y material o sustancial, salvo los casos en que ella sea revisable, mediante algún procedimiento o trámite por el propio Tribunal Constitucional, o cuando el Estado ha reconocido jurisdicción en la materia a un Tribunal supra o transnacional a cuyas sentencias se le ha reconocido carácter jurídico vinculante y el Estado tiene una obligación de resultado de ejecutar la sentencia, lo que puede implicar anular o revisar eventualmente la sentencia de su Tribunal Constitucional nacional.

Así ocurre también en República Dominicana, donde la Constitución de 2010, determina en su artículo 184, que "Sus decisiones son definitivas e irrevocables y constituyen precedentes vinculantes para los poderes públicos y todos los órganos del Estado".

\subsubsection{1.) La cosa juzgada formal y material}

Es normal que en los diferentes países el Poder Judicial cuente con variados grados e instancias, en cada uno de los cuales el fallo del respectivo tribunal o corte tendrá valor de cosa juzgada formal, al existir recursos que permiten impugnar dicha sentencia ante tribunales o cortes superiores. Así, solo la sentencia del tribunal o corte superior del respectivo ordenamiento jurídico tendrá valor de cosa juzgada formal, salvo el caso que

12 Bernal Pulido, Carlos. (2005). El derecho de los derechos. Bogotá: Ed. Universidad Externado de Colombia, 419 pp. p. 150. 
existan instancias supranacionales en la materia, como son por ejemplo el Tribunal Penal Internacional o Cortes de Derechos Humanos a las cuales se les ha reconocido a sus fallos carácter vinculante por el respectivo Estado. Obviamente, una sentencia de un tribunal de un grado o instancia inferior podrá tener carácter de cosa juzgada formal, si ella no es impugnada dentro de los plazos contemplados en el ordenamiento jurídico ante una instancia superior.

En el caso de la jurisdicción constitucional concentrada siempre el fallo del Tribunal o Corte Constitucional produce cosa juzgada formal, en materia de control reparador abstracto o concreto, ya que ella no puede ser revisada por otro órgano jurisdiccional nacional ${ }^{13}$.

La cosa juzgada material implica la inmutabilidad del fallo ad extra, vale decir, la imposibilidad de reabrir el debate sobre el contenido de lo fallado a través de otro proceso o procedimiento, por ejemplo la determinación de la constitucionalidad de un determinado enunciado legal. Esta cosa juzgada material se produce cuando la resolución del juez constitucional resuelve el fondo del asunto suscitado por el contenido normativo de un precepto, imposibilitando replantear el asunto ya definido, produciendo la intangibilidad del fallo.

Puede sostenerse que en la sentencia constitucional la cosa juzgada formal recae sobre enunciados jurídicos, mientras que la cosa juzgada material recae sobre normas emanadas de los enunciados jurídicos.

En el ámbito de la jurisdicción constitucional la cosa juzgada material no siempre se produce.

Hay casos en que producido un primer pronunciamiento del Tribunal Constitucional a requerimiento de un órgano estatal, en el cual se determina la constitucionalidad del enunciado legal impugnado, puede vol-

13 El Decreto 2067 de 1991 que regula el procedimiento de inconstitucionalidad en Colombia, en su artículo 21, precisa que, "Las sentencias que profiera la Corte Constitucional tendrán el valor de cosa juzgada constitucional y son de obligatorio cumplimiento para todas las autoridades y los particulares", todo ello en armonía con el artículo 45 de la Ley Estatutaria 270 de 1996. El parágrafo $2^{\circ}$ del artículo 21 en consideración agrega que "La declaratoria de constitucionalidad de una norma impugnada por vicios de forma no obsta para que esta sea demandada posteriormente por razones de fondo". El artículo 23 del Decreto 2067 ańade que "La doctrina constitucional enunciada en las sentencias de la Corte Constitucional, mientras no sea modificada por esta, será criterio auxiliar para las autoridades y corrige la jurisprudencia", todo ello en armonía con el artículo 48 de la Ley Estatutaria 270.

El Código Procesal Constitucional del Perú, Ley N²8.237 de 2004, vigente desde diciembre de 2004, precisa en su artículo 82 que "Las sentencias del Tribunal Constitucional en los procesos de inconstitucionalidad... que queden firmes tienen autoridad de cosa juzgada, por lo que vinculan a todos los poderes públicos y producen efectos generales desde el día siguiente a la fecha de su publicación". (Lo destacado es nuestro).

El artículo 88 de la Ley de Jurisdicción Constitucional de Costa Rica determina que las sentencias que declaren la inconstitucionalidad y pronuncian la anulación consecutiva de la norma ... "producirán cosa juzgada y eliminarán la norma o acto del ordenamiento jurídico". 
verse a impugnar la constitucionalidad del mismo enunciado normativo por otro órgano o persona legitimado activamente para ello, pudiendo la Corte Constitucional, en este segundo caso, determinar la inconstitucionalidad de dicho enunciado normativo, eliminándolo del ordenamiento jurídico, eventualmente con efectos ex tunc (retroactivos). En dicha hipótesis no podría seńalarse que el primer fallo tuvo efectos de cosa juzgada constitucional material, ya que este fue enervado por la segunda sentencia en que el mismo Tribunal cambió de criterio. Esto puede ocurrir por ejemplo, en el caso de Costa Rica, donde las sentencias de la Sala Constitucional de la Corte Suprema son vinculantes para todos los tribunales de la República, salvo para la propia Sala Constitucional seńalada, así lo establece la Ley de Jurisdicción Constitucional 7135, en su artículo 87, el cual determina que "las resoluciones o sentencias que denieguen la inconstitucionalidad unicamente surtirán efectos entre las partes en el caso concreto y no producirán cosa juzgada. La acción de inconstitucionalidad podrá ejercerse contra normas o actos previamente declarados constitucionales y en casos o procesos distintos". A través de este tipo de regulaciones se posibilita la revisión de criterios del juez constitucional en casos anteriores.

Por otra parte, en el ámbito de la jurisdicción constitucional, puede darse el caso que los fallos del Tribunal o Corte Constitucional que determinen la constitucionalidad de un enunciado legal afirmado en un control preventivo abstracto de control de constitucionalidad, pueda ser nuevamente analizado en un proceso diferente de control reparador concreto de inaplicabilidad por inconstitucionalidad, determinando que dicho enunciado legal declarado constitucional en abstracto en su aplicación en la gestión judicial específica pueda generar un efecto inconstitucional y así declararlo el Tribunal Constitucional, si lo estima pertinente, lo que puede perfectamente ocurrir en Chile, considerando en la primera hipótesis la aplicación de los artículos $93 \mathrm{~N}^{\circ} 1^{\circ}$ o $3^{\circ}$ y en la segunda hipótesis la aplicación del artículo $93 \mathrm{No}^{\circ}$. En todo caso, como seńala la LOC del Tribunal Constitucional, la inaplicabilidad no podrá ser declarada por el mismo vicio materia del proceso en el control preventivo de constitucionalidad.

\subsection{2.) La cosa juzgada absoluta, la relativa y la aparente}

Si el Tribunal Constitucional se pronuncia determinando que un enunciado legal sometido a su análisis es constitucional, es preciso que dicho estudio se haya efectuado sobre todos los aspectos en que puede incidir el enunciado normativo respectivo, eliminando eventuales otras posibles razones de inconstitucionalidad que no fueron planteadas por el requirente. Si ello no fuera así, los efectos de cosa juzgada de dicha sentencia no son absolutos y solo tendrán el carácter de cosa juzgada relativa. 
La existencia de una cosa juzgada relativa existirá en el caso en que el Tribunal Constitucional, en el momento de hacer su análisis, no haya tenido en consideración determinadas hipótesis posibles de inconstitucionalidad del enunciado normativo, lo que puede reconocerse de dos maneras posibles.

La primera, cuando el propio Tribunal Constitucional en el fallo seńala que su análisis solo consideró los aspectos impugnados por la parte demandante, en cuyo caso los efectos de cosa juzgada son relativos únicamente a esa dimensión del análisis, pudiendo presentarse nuevas demandas de inconstitucionalidad del enunciado normativo basado en cuestiones distintas no consideradas en el fallo inicial.

La segunda forma posible de reconocer una realidad de cosa juzgada relativa, es cuando el Tribunal Constitucional nada dice en la sentencia de haber examinado el enunciado normativo solo desde determinados ángulos, por lo cual podría presumirse que lo hizo desde todos los enfoques posibles, en tal caso, la cosa juzgada sería absoluta; sin embargo, ello no sería así si del análisis de los fundamentos del fallo en que se resolvió el caso, no existe elemento alguno que permita considerar razonablemente que se tuvo en consideración el nuevo problema constitucional planteado en la nueva demanda, en esta última hipótesis, puede sostenerse con fundamento suficiente que el primer fallo tiene solo efectos de cosa juzgada relativa.

Además de distinguir entre cosa juzgada absoluta y relativa, es necesario tener presente la situación de cosa juzgada aparente. Esta situación ocurre cuando al sustentar una decisión de constitucionalidad o inconstitucionalidad, el Tribunal Constitucional no ha establecido los fundamentos racionales y jurídicos de la decisión en que se declara uno entre otros textos jurídicos como constitucionales. En tal caso, solo existe cosa juzgada aparente ya que no se ha examinado fundadamente si el texto normativo específico en confrontación con la Carta Fundamental es constitucional o inconstitucional. No debe olvidarse que una sentencia de un órgano que ejerce jurisdicción debe ser motivada, fundada en las fuentes del derecho vigente, y congruente. No existe fallo ni cosa juzgada sin adecuado sustento jurídico de la decisión, ya que sería una sentencia írrita o arbitraria, una situación de hecho y no una verdadera sentencia. No olvidemos que en esta materia, la Corte Interamericana de Derechos Humanos ha declarado varias sentencias de tribunales superiores como írritas o como vías de hecho revestidas de formalidades jurídicas, determinando su nulidad por violación de derechos humanos, relativizando la res iudicata y el non bis in idem, obligando a desarrollar nuevos procesos, en el caso chileno, puede mencionarse a manera ejemplar el caso Almonacid Arellano contra Chile. 
La cosa juzgada aparente ha sido reconocida hidalgamente por algunos tribunales constitucionales, a modo de ejemplo, seńalaremos a la Corte Constitucional colombiana. En efecto, la Corte debió analizar la constitucionalidad del Decreto 663 de 1993, Estatuto Orgánico del Sistema Financiero, que contenía normas que configuraban el sistema de financiamiento de viviendas a largo plazo. La Corte encontró que dicha normativa era inconstitucional, pero surgió en el Pleno la objeción acerca de la posible cosa juzgada que existía en la materia, ya que la Corte Constitucional, desde 1994, había dictado una sentencia que había sostenido que todo el Decreto 663, del cual hacían parte las disposiciones actualmente impugnadas, era constitucional. La Corte Constitucional examinó minuciosamente la sentencia que ella había dictado en 1994, en la que constató que había omitido todo análisis del Decreto 663 de 1993, el cual aparecía declarado constitucional entre muchas otras disposiciones que en dicha oportunidad habían sido demandadas de inconstitucionalidad, apareciendo la referencia al Decreto 663 en la parte resolutiva del fallo, no teniendo la parte motiva o los considerandos del mismo la más mínima referencia al contenido de dicho Decreto y a su confrontación con la Constitución. Así, la sentencia de la Corte Constitucional C-700 de 1999, debió reconocer que respecto de dicha disposición normativa en la sentencia de 1994 había sólo una apariencia de cosa juzgada.

La afirmación de Jackson sobre la Corte Suprema norteamericana de que es infalible porque tiene la última palabra, ya no puede formularse con tanta claridad en estos inicios del siglo XXI en nuestros países, donde operan jurisdicciones supranacionales en materia de derechos humanos, o Cortes Penales Internacionales, como asimismo, cuando se encuentran consolidados procesos de integración supranacional, instituciones todas que obligan a flexibilizar la perspectiva señalada.

Así, en materia de derechos fundamentales o humanos, los tribunales constitucionales no son la última palabra, esta es la Corte Interamericana de Derechos Humanos ${ }^{14}$, en nuestro ámbito regional.

14 A modo de ejemplo, en el Caso: Castillo Petruzzi y otros con Perú, la Corte Interamericana anuló el fallo del órgano judicial máximo de la jurisdicción militar peruana y ordenó al Estado peruano realizar un nuevo juicio a los afectados respetando las normas de un tribunal independiente e imparcial y un procedimiento que cumpliera con las normas del debido proceso, lo que fue acatado por el Estado peruano, anulando la sentencia anterior y realizándose el nuevo procedimiento ajustado a las reglas del debido proceso por un tribunal ordinario preestablecido de carácter independiente e imparcial. En el caso Almonacid Arellano con Chile determinó reabrir el caso por un juez natural competente, dejando sin efecto las resoluciones judiciales de sobreseimiento definitivo por amnistía por la judicatura militar y la resolución de la Corte Suprema de Justicia que trasladaba la competencia del juez ordinario a la justicia militar. 
Ello ha llevado a diversas constituciones a reconocerlo explícitamente en la Carta Fundamental: La Constitución peruana de 1993 contempla dicha situación, en su artículo 205, el cual precisa que, Agotada la jurisdicción interna, quien se considere lesionado en los derechos que la Constitución reconoce puede recurrir a los tribunales $u$ organismos internacionales constituidos según tratados o convenios en que Perú es parte.

El Código Procesal Constitucional peruano, en su artículo 115, se refiere a la materia precisando que

"Las resoluciones de los organismos jurisdiccionales a cuya competencia se haya sometido expresamente el Estado peruano no requieren, para su validez y eficacia, de reconocimiento, revisión, ni examen previo alguno. Dichas resoluciones son comunicadas por el Ministerio de Relaciones Exteriores al Presidente del Poder Judicial, quien a su vez, las remite al tribunal donde se agotó la jurisdicción interna y dispone su ejecución por el juez competente, de conformidad con lo previsto por la Ley $N^{\circ} 27.775$, que regula el procedimiento de ejecución de sentencias emitidas por tribunales supranacionales".

A su vez, la Constitución venezolana de 1999, en su artículo 31, determina que

Toda persona tiene derecho, en los términos establecidos por los tratados, pactos y convenciones de derechos humanos ratificados por la República, a dirigir peticiones o quejas ante los órganos internacionales creados para tales fines, con el objeto de solicitar el amparo a sus derechos humanos. El Estado adoptará, conforme a procedimientos establecidos en esta Constitución y la ley, las medidas que sean necesarias para dar cumplimiento a las decisiones emanadas de los órganos internacionales previstos en este artículo.

A su vez, puede sostenerse en esta materia que una institución que tiene como finalidad una certeza formal como es la institución de la cosa juzgada, no puede prevalecer sobre la protección efectiva y constante de los derechos humanos, los que, además, en parte importante del derecho sudamericano son parte del bloque constitucional de derechos por haberse incorporado a la Constitución material y en algunos casos, a la Constitución formal, los tratados sobre derechos humanos (Argentina, Ecuador, Venezuela, Costa Rica, Guatemala, a modo ejemplar), y en Chile, los derechos en cuanto atributos de la persona humana, independientemente de su envase normonológico (Constitución o Derecho Internacional) constituyen límites a la potestad estatal, como lo establece perentoriamente el artículo $5^{\circ}$ inciso segundo de la Constitución y lo ha concretado el Tribunal Constitucional en sus fallos ${ }^{15}$. 


\section{5) LOS EFECTOS DE LA SENTENCIA DE INCONSTITUCIONALIDAD EN EL TIEMPO}

Otro aspecto independiente de los anteriores es qué sucede con los actos jurídicos realizados bajo el imperio eficaz del precepto jurídico declarado inconstitucional y nulo por el juez constitucional y por tanto, separado o expulsado del ordenamiento jurídico.

Sobre esta materia el texto constitucional dominicano nada señala, será el legislador el que determinará los efectos de la sentencia de inconstitucionalidad en el tiempo, aplicando efectos ex nunc, producen efectos desde la publicación de la sentencia, por regla general, sin embargo, el artículo 48 de la ley, determina que el Tribunal Constitucional "podrá reconocer y graduar excepcionalmente, de modo retroactivo, los efectos de sus decisiones de acuerdo a las exigencias del caso", línea que es seguida por diferentes jurisdicciones constitucionales latinoamericanas con matices ${ }^{16}$

16 En el caso chileno, la Constitución no asume la hipótesis de desvincular la decisión de separar el precepto jurídico inconstitucional del ordenamiento jurídico de la determinación de qué pasa con los actos jurídicos desarrollados mientras el precepto expulsado del ordenamiento tuvo vigencia. El texto del inciso $3^{\circ}$, frase final del artículo 94 de la Constitución, quedó en la Carta Fundamental en los siguientes términos: "No obstante, el precepto declarado inconstitucional en conformidad a lo dispuesto en los numerales 2,4 ó 7 del Artículo 93, se entenderá derogado desde la publicación en el Diario Oficial de la sentencia que acoja el reclamo, la que no producirá efectos retroactivos".

El artículo 27 de la Ley No 9.868 brasilera de 1999, que regula la acción directa de inconstitucionalidad, determina que: "al declarar la inconstitucionalidad de la ley o acto normativo, y teniendo en vista razones de seguridad juridica o de excepcional interés social, podrá el Supremo Tribunal Federal, por mayoría de dos tercios de sus miembros, restringir los efectos de dicha declaración o decidir que ella solo tenga eficacia a partir de su tránsito en juzgado o de otro momento que venga a ser fijado", lo que rompe con la regla de la eficacia ex tunc de la sentencia declaratoria de inconstitucionalidad.

El artículo 45 de la Ley Estatutaria de la Administración de Justicia de Colombia determina que las sentencias que profiera la Corte Constitucional sobre los actos sujetos a su control "tienen efectos hacia el futuro a menos que la Corte resuelva lo contrario", norma que fue declarada exequible, vale decir, conforme con la Constitución, por la Sentencia de la Corte Constitucional C-037 de 1996. Sobre la materia hay diversos pronunciamientos de la Corte Constitucional, así en sentencia C-113/93 declaró que los fallos de la Corte tendrán efecto hacia el futuro, salvo para garantizar el principio de favorabilidad en materia penal, policiva y disciplinaria y en el caso previsto en el artículo 149 de la Constitución. A su vez, en sentencia C-037/96 la Corte Constitucional colombiana fijó algunos criterios de modulación de los fallos en el tiempo, precisando que "Los efectos concretos de la sentencia de inexequibilidad dependerán entonces de una ponderación, frente al caso concreto, del alcance de dos principios encontrados: la supremacía de la Constitución -que aconseja atribuir a la decisión efectos ex tunc, esto es, retroactivos- y el respeto a la seguridad jurídica -que, por el contrario, sugiere conferirle efectos ex nunc, esto es únicamente hacia el futuro-".

A su vez, la Ley Orgánica de Tribunal Supremo de Venezuela de 2004, establece en su artículo 21 , párrafo $18^{\circ}$, que en el fallo definitivo en que se pronuncia sobre la nulidad por inconstitucionalidad de normas o actos impugnados de inconstitucionalidad, una vez examinados los motivos en que se funda la demanda, "determinará, en su caso, los efectos de la decisión en el tiempo". 
de acuerdo a las particularidades de cada caso, o si el tema será regulado por la ley del Tribunal Constitucional. El tema tiene su complejidad ya que algunos tribunales constitucionales, cuando los efectos en el tiempo no están determinados constitucionalmente han seńalado que ellos son quienes tienen la competencia para determinarlos, no teniendo competencia la ley, como lo determinó la Corte Constitucional Colombiana en su caso.

Los efectos del precepto jurídico determinado como inconstitucional es un problema empírico que no se encuentra resuelto por la decisión de inconstitucionalidad y tampoco por la resolución que priva de eficacia al precepto inconstitucional hacia el futuro, lo que significa un pronunciamiento sobre borrar o validar los efectos cumplidos en el pasado, lo que debe ser decidido por el juez constitucional, ya que la sentencia constitucional ocupa el lugar dejado por el precepto jurídico inconstitucional y nulo.

Ni siquiera el Tribunal Constitucional desarrollado bajo la inspiración del concepto de legislador negativo de Kelsen, establece una rigidez entre la nulidad y los efectos de la sentencia en el tiempo.

Al efecto, la Constitución de Austria, en su artículo 140.5 precisa,

El fallo del Tribunal Constitucional por el que se anule una ley como anticonstitucional, obliga al Canciller Federal o al Gobernador Regional competente a publicar sin demora la derogación. Se aplicará este precepto por analogía al caso de las acciones interpuestas al amparo del párrafo 4. La anulación entrará en vigor el día de la promulgación, si el Tribunal Constitucional no hubiere fijado un plazo para la expiración de la vigencia. Dicho plazo no podrá exceder de un año.

A su vez, el artículo 140.7 determina,

Anulada una ley como inconstitucional o pronunciada sentencia por el Tribunal Constitucional, quedarán vinculados a dicho fallo cualesquiera tribunales y órganos administrativos. Sin embargo, se seguirá aplicando la ley en cuestión a las situaciones de hecho consumadas antes de la anulación, excepto aquella que haya dado origen al fallo, si el Tribunal Constitucional no hubiere dispuesto otra cosa en su fallo derogatorio. Si el Tribunal Constitucional hubiese fijado en dicho fallo un plazo conforme a lo previsto en el párrafo 5 , la ley se aplicará a todos los hechos que se consumen antes a que expire el plazo, con excepción precisamente del caso que dio origen a la sentencia.

El Tribunal austríaco, inspirado en el modelo kelseniano, de acuerdo con las normas constitucionales citadas, al determinar la nulidad de la norma inconstitucional los efectos de ella son que dicha nulidad no tiene efectos sobre los actos desarrollados durante la eficacia de la norma inconstitucional en el pasado, sino solo efectos ex nunc o pro futuro por 
regla general, sin perjuicio de posibilitar que el propio Tribunal module sus sentencias en el tiempo dentro de ciertos límites, los efectos pueden ser inmediatos o prospectivos en el tiempo hasta un máximo de un ańo. Schäfer en su estudio sobre la materia, señala que, pese a la rigidez del sistema, en algunos casos el Tribunal Constitucional ha dado efectos retroactivos a sus fallos, como ocurrió en 1996, en un caso de saneamiento presupuestal, el Tribunal Constitucional consideró que dicho gravamen era desproporcionado e inconstitucional, como se trataba de un procedimiento especial (Anlabfälle), donde se habían presentado cerca de once mil recursos, el Tribunal tomó la determinación que los efectos del fallo que había favorecido a algunos contribuyentes, se extendiera a todos los casos decididos según la norma objeto de control, concediendo claros efectos retroactivos al fallo en virtud del principio de igualdad, anulando la carga impositiva de forma general y con efectos ex tunc ${ }^{17}$.

De la innecesaria rigidez aprendida de la experiencia de los tribunales constitucionales europeos, las constituciones y legislaciones sudamericanas han extraído la necesaria flexibilidad que debe ser dejada al juez constitucional para modular los efectos de la nulidad en el tiempo.

\section{6) CONSIDERACIONES SOBRE LOS EFECTOS DE LA SENTENCIA CONSTI- TUCIONAL EN EL ÁMBITO PERSONAL}

En lo referente a los efectos del fallo respecto de las personas, la sentencia de los tribunales constitucionales pueden tener efectos inter partes, el fallo determina la inaplicación del precepto legal considerado contrario a la Constitución para el caso concreto, afectando la sentencia solo a las partes que han actuado en el respectivo contencioso; o pueden tener efectos erga omnes, si la decisión es vinculante respecto de todos, lo que otorga a la sentencia una fuerza similar a la que detenta el Poder Legislativo, pero de carácter inverso, al eliminar el precepto normativo del ordenamiento jurídico, que es la regla general en el caso de las acciones abstractas de inconstitucionalidad que se concretan cuando el precepto impugnado ya forma parte del ordenamiento jurídico (control represivo o reparador). Así ocurre también en el caso del Tribunal Constitucional de República Dominicana, de acuerdo con el artículo 45 de la Ley No 13711.

En el contexto latinoamericano, los tribunales constitucionales por regla general establecen como efectos temporales los efectos erga omnes. Así ocurre con las sentencias de los tribunales constitucionales de Bolivia

SChäfer, Heinz, (1998). "Austria: la relación entre el Tribunal Constitucional y el Legislador" en Aja, Eliseo (ed.). Las tensiones entre el Tribunal Constitucional y el Legislador en la Europa Actual. Barcelona: Ariel Derecho, pp. 37-38 
respecto de las sentencias en recurso directo y abstracto de inconstitucionalidad $^{18}$; de Colombia, las sentencias sobre acciones, revisión previa y control automático y obligatorio de constitucionalidad de preceptos legales $^{19}$; Ecuador, respecto de las acciones de carácter directo y abstracto ${ }^{20}$; Perú, respecto de las acciones abstractas y directas ${ }^{21}$; y de las acciones directas y abstractas ante la Sala Constitucional del Tribunal Supremo de Venezuela ${ }^{22}$.

\section{1.) LA EXISTENCIA O INEXISTENCIA DE PRECEDENTE Y DE FUERZA VINCULANTE DE LAS SENTENCIAS DEL TRIBUNAL CONSTITUCIO- NAL}

La Constitución Dominicana de 2010, en su articulo 184, determina que las decisiones del Tribunal Constitucional son "definitivas e irrevocables y constituyen precedentes vinculantes para los poderes públicos y todos los órganos del Estado". Ello se refleja en la ley la Ley No 137-11 del Tribunal Constitucional de República Dominicana, el artículo 31 determina que las decisiones del Tribunal Constitucional "son definitivas e irrevocables $y$ constituyen precedentes vinculantes para los poderes públicos y todos los órganos del Estado".

La superioridad de la Constitución, lleva a la superioridad del intérprete de la Constitución que es el Tribunal Constitucional, el que se constituye en el órgano de cierre del ordenamiento jurídico por sobre la ley, la cual es objeto de enjuiciamiento sobre su constitucionalidad. Todo ello, sin perjuicio de reconocer que no es el único intérprete jurisdiccional de la Constitución, ya que los jueces ordinarios deben siempre realizar interpretación constitucional al aplicar el ordenamiento jurídico a partir de la Constitución en una interpretación conforme a la Constitución.

La declaración de constitucionalidad o inconstitucionalidad por parte del Tribunal Constitucional que produce cosa juzgada es la parte resolutiva de la sentencia, aun cuando ella se explica por los argumentos jurídicos expuestos en la parte considerativa de la sentencia. El carácter de precedente consiste en el respeto de los criterios conformadores de la doctrina elaborada por el juez constitucional en la ratio decidendi o holding del fallo. Puede sostenerse que lo que trasciende la cosa juzgada del caso, es la eventual fuerza del precedente y la eventual fuerza vinculante de este, como los eventuales efectos erga omnes del fallo.

18 Artículo 58 de la Ley del Tribunal Constitucional.

19 Artículo 47 de la Ley Estatutaria de la Administración de Justicia (Ley No 270 de 1996) y 21 del Decreto 2067 de 1991.

20 Artículo 22 de la Ley de Control Constitucional de 1997.

21 Artículo 204 de la Constitución Peruana de 1993.

22 Artículo 336 de la Constitución Venezolana de 1999. 
La regla general en el derecho constitucional comparado europeo y latinoamericano es que el efecto de la sentencia constitucional más allá de lo determinado en la parte resolutiva del fallo para el conflicto específico, se comprende si se asume que la función de un Tribunal Constitucional es determinar la norma que emana del enunciado constitucional para hipótesis específicas y su utilización uniforme por los diferentes órganos constitucionales, vinculando así la conducta futura de órganos y personas, evitando que comportamientos declarados inconstitucionales vuelvan a repetirse o que se interpreten normas de una manera diferente a la declarada por el Tribunal Constitucional, otorgando una cierta seguridad jurídica de los caminos por los cuales los órganos y personas pueden transitar en el marco de la Carta Fundamental.

Una sentencia de un Tribunal Constitucional tiene un alcance más pleno cuando de ella se deriva, además de su carácter declarativo que permite eliminar el vicio constitucional en el caso específico, la fuerza vinculante que establece el deber de los demás órganos estatales de seguir, de buena fe, en casos idénticos o de la misma clase los principios determinados por el Tribunal Constitucional. Tales principios se encuentran en la parte considerativa o motiva del fallo constitucional, constituyendo la "ratio decidendi" del mismo, pasando a tener una fuerza jurídica similar a la norma jurídica interpretada ${ }^{23}$.

La regla de la vinculatoriedad de los fallos es común en el derecho y en la jurisprudencia de los tribunales constitucionales de nuestro círculo de cultura jurídica. Esta perspectiva implica que basta que el Tribunal Constitucional o el órgano de jurisdicción constitucional centralizado o concentrado competente dicte una resolución o sentencia sobre el alcance de cualquier norma infraconstitucional, para que, cualquier interpretación divergente de los tribunales ordinarios y especiales para casos análogos se vuelva imposible, de acuerdo con las normativas legales precisadas, si no hay una razón fuerte que demuestre la existencia de elementos del caso lue lo hagan diferente a lo ya resuelto o que no se hayan tenido en consideración argumentos nuevos que desarrolla en la nueva sentencia el respectivo tribunal.

El tema de la vinculación del precedente está relacionado con el tema de la decisión, lo que lleva a una utilización restrictiva y limitada del precedente, a los casos efectivamente análogos, como asimismo considerando como precedente solamente los principios y reglas contenidas en el holding o ratio decidendi de la sentencia, no pudiendo extenderse a consideraciones periféricas contenidas en el fallo.

Ver sobre la materia Tupayachi Sotomayor, Johnny (coord). (2009). El precedente constitucional vinculante en el Perú (análisis, comentarios y doctrina comparada). Lima: Ed. Adrus - Instituto Iberoamericano de Derecho Constitucional, sección Peruana. 869 pp. 
Asimismo, ello obliga a distinguir los tres sectores o elementos estructurales del cuerpo de la sentencia o fallo, el denominado holding o ratio decidendi, el dictum u oviter dicta o simplemente dicta, y el rationale ${ }^{24}$.

La distinción entre la ratio decidendi y el oviter dicta o dictum, está dada porque el primero de estos conceptos es la parte del fallo que fundamenta directa e inmediatamente el precedente, estableciendo la regla o principio que define el tribunal al resolver el problema o caso sometido a su consideración, mientras que el segundo concepto, el oviter dicta o dictum, se refiere a los razonamientos marginales periféricos o circunstanciales, los cuales carecen de valor vinculante con efecto erga omnes

En todo caso consideramos necesario introducir un matiz, en virtud del principio de independencia judicial también generalmente reconocida constitucionalmente, estableciendo que, excepcionalmente, los jueces en el ejercicio de su autonomía judicial podrían apartarse del precedente, motivando suficiente y adecuadamente las razones de la separación de la línea jurisprudencial trazada por el Tribunal Constitucional, de lo contrario estarían infringiendo el derecho de las personas a la igualdad ante la ley y el principio de seguridad jurídica.

El problema más significativo en esta materia se presenta cuando los tribunales ordinarios en un caso concreto consideren la inaplicación del precedente del Tribunal Constitucional en el caso que están conociendo, por considerar que las propiedades del mismo son diferentes (distinguish), vale decir, cuando el juez o tribunal ordinario, consideren que existen diferencias relevantes que median entre el caso resuelto mediante el precedente y el caso que debe resolver actualmente el juez ordinario, por lo que la ratio decidendi del primer caso no puede aplicarse al segundo, exigiendo este último una solución diferente, como asimismo, cuando el precedente no responda adecuadamente a un cambio social posterior por variación de las circunstancias; o cuando se modifica el precedente (overruling) al considerarlo erróneo desde una perspectiva axiológica, al ser contrario a los valores, principios y derechos en que se fundamenta el ordenamiento jurídico.

En la materia Castillo Córdova en Perú, ha afirmado que "todas las razones suficientes o ratio decidendi en una sentencia constitucional, en particular las que en ella son formuladas como precedentes vinculantes, son normas constitucionales implícitas o adscritas a la norma constitucio-

24 Sobre la materia puede consultarse, Magaloni Kerpel, Ana Laura. (2001). El precedente constitucional en el sistema judicial norteamericano. Madrid: McGraw Hill. 216 pp. Asimismo, Escovar León, Ramón. (2005). El precedente y la interpretación constitucional. Caracas, Ed. Sherwood. 
nal directamente estatuida, objeto de interpretación y en relación a la cual se ha formulado el precedente vinculante" 25 .

A modo ejemplar, citaremos algunas normas en países que siguen el sistema jurídico romano germánico:

La Ley de la Corte Constitucional Federal alemana, en su artículo 31, prescribe:

"1. Las decisiones del Tribunal Constitucional Federal vinculan a los órganos constitucionales de la Federación y de los Estados así como a los tribunales y autoridades.

"2. En los casos del 13 números 6, 11, 12 y 14, la decisión del Tribunal Constitucional federal tiene fuerza de ley. Esto se aplica también en los casos del $13^{\circ} \mid 8$ (sobre recursos de amparo), cuando el Tribunal Constitucional Federal declara la compatibilidad o incompatibilidad y la nulidad de una ley. En tanto que una ley sea declarada compatible o incompatible con la Ley Fundamental o con el derecho federal, o sea declarada nula, la decisión deberá ser publicada por el Ministerio Federal de Justicia en el Boletín Oficial Federal, lo mismo se aplica para las decisiones dictadas en los casos del 13 números 12 y 14”.

Comentando esta norma de la Ley de la Corte Constitucional alemana, Raúl Bocanegra, determina que "mientras la noción de vinculación a las sentencias constitucionales extiende sus efectos a todos los órganos constitucionales, autoridades y tribunales, la fuerza de ley se extendería no solo como aquella al Estado y a sus órganos, sino, mas allá, también a todos, personas físicas y jurídicas que podrían invocar a su favor estas decisiones y a todos obligarían produciendo directamente para todos los derechos y obligaciones, puesto que todos están obligados por las leyes, no solamente las partes intervinientes en el proceso, como ocurre con la cosa juzgada o los órganos del Estado, como sucede con los efectos de vinculación" 26 .

La Ley Orgánica del Tribunal Constitucional español, en su Arturo 40.2. determina:

"La jurisprudencia de los tribunales de justicia recaida sobre leyes, disposiciones o actos enjuiciados por el Tribunal Constitucional habrá de entenderse corregida por la doctrina derivada de las sentencias y autos que resuelvan los recursos y cuestiones de inconstitucionalidad".

25 Castillo Córdoba, Luis. (2009). "La jurisprudencia vinculante del Tribunal Constitucional" en Tupayachi Sotomayor, Jhonny (coord). (2009). El precedente constitucional vinculante en el Perú (análisis, comentarios y doctrina comparada). Lima: Ed. Adrus - Instituto Iberoamericano de Derecho Constitucional, sección peruana, p. 653. 
A su vez, la Ley Orgánica del Poder Judicial de España 6 de 1985 de 1 de julio, señala en su artículo 5.1. precisa:

"La Constitución es la norma suprema del ordenamiento jurídico y vincula a todos los jueces y tribunales, quienes interpretarán y aplicarán las leyes $y$ los reglamentos según los preceptos y principios constitucionales, conforme a la interpretación de los mismos que resulte de las resoluciones dictadas por el Tribunal Constitucional en todo tipo de procesos".

El Supremo Tribunal Federal de Brasil, según el artículo 28 de la Ley 9868/99, en su párrafo único, determina que las declaraciones de constitucionalidad, inclusive la interpretación conforme a la Constitución, tienen eficacia contra todos, y efecto vinculante en relación a los órganos del Poder Judicial y a la administración pública federal, estadual y municipal $^{27}$.

El Código Procesal Constitucional del Perú, en su artículo VI, inciso $3^{\circ}$, señala que "Los jueces interpretan y aplican las leyes o toda norma de rango de ley y los reglamentos según los preceptos y principios constitucionales, conforme a la interpretación de los mismos que resulte de las resoluciones dictadas por el Tribunal Constitucional".

El Código Procesal Constitucional del Perú, el cual en su artículo VII, sobre la misma materia precisa:

"Precedente. Las sentencias del Tribunal Constitucional que adquieren la autoridad de Cosa Juzgada constituyen precedente vinculante cuando así lo exprese la sentencia, precisando el extremo de su efecto normativo. Cuando el Tribunal Constitucional resuelva apartándose del precedente, debe expresar los fundamentos en los que sustenta tal decisión".

La Constitución de Bolivia de 2009, en su artículo 203, precisa que las decisiones y sentencias del Tribunal Constitucional Plurinacional son de carácter vinculante y de cumplimiento obligatorio, y contra ellas no cabe recurso ordinario ulterior alguno.

En el caso colombiano, el artículo 48 de la Ley 270 Estatutaria de la Administración de Justicia de 1996 de conformidad con el artículo 230 de la Constitución, establece algunas regulaciones en la materia, determina expresamente que "solo será de obligatorio cumplimiento y con efectos erga omnes la parte resolutiva de los fallos. La parte motiva constituye sólo criterio auxiliar para la actividad judicial y para la aplicación de las normas de derecho en general". El artículo 23 del Decreto 2067 de Colombia señala que "La doctrina constitucional enunciada en las sentencias de la Corte Constitucional, mientras no sea modificada por esta, será criterio auxiliar para las autoridades y corrige la jurisprudencia".

27 Afonso Da Silva, Virgilio. (2004). "La interpretación conforme a la Constitución. Entre la trivialidad y la centralización judicial”, en Cuestiones Constitucionales. Revista Mexicana de Derecho Constitucional. Ciudad de México. p. 21. http//www:juridicas.unam.mx/publica/ $\mathrm{rev} / \mathrm{cconst} / \mathrm{cont} / 12 / \mathrm{ard} / \mathrm{ard} 1 . \mathrm{htm}$ 
La doctrina de la Corte Constitucional colombiana ha establecido el carácter vinculante de sus interpretaciones, utilizando para ello la técnica del precedente, distinguiendo entre la argumentación que guarda relación directa y necesaria con la parte resolutiva del fallo de aquella que solo es tangencial ${ }^{28}$.

La Corte Constitucional colombiana en sentencia C-447 de 1997, precisa: "Todo tribunal, y en especial la Corte Constitucional, tiene la obligación de ser consistente con sus decisiones previas. Ello deriva no solo de elementales consideraciones de seguridad jurídica -pues las decisiones de los jueces deben ser razonablemente previsibles- sino también del respeto del principio de igualdad, puesto que no es justo que casos iguales sean resueltos de manera distinta por un mismo juez. Por eso, algunos sectores de la doctrina consideran que el respeto al precedente es al derecho lo que el principio de universalización y el imperativo categórico son a la ética, puesto que es buen juez aquel que dicta una decisión que estaría dispuesto a suscribir en otro supuesto diferente que presente caracteres análogos, y que efectivamente lo hace. Por ello la Corte debe ser muy consistente y cuidadosa en el respeto de los criterios jurisprudenciales que han servido de base (ratio decidendi) de sus precedentes decisiones" 29.

La Ley de Amparo, exhibición personal y de constitucionalidad de Guatemala, en su artículo 43 precisa:

"La interpretración de las normas contenidas en la Constitución y de otras leyes contenidas en las sentencias de la Corte de constitucionalidad, sienta doctrina legal que debe respetarse por los tribunales al haber tres fallos contestes de la misma Corte".

La Sala Constitucional del Tribunal Supremo de Justicia de Venezuela, en base al artículo 335 de la Constitución de 1999, establece la obligatoriedad de las interpretaciones constitucionales determinadas por la Sala Constitucional con motivo de la resolución de controversias o de una solicitud de interpretación. La Sala Constitucional ha resuelto que la norma general producida por la interpretación abstracta genera efectos erga omnes, "constituyendo una verdadera jurisdatio, una interpretación cuasi auténtica o para constituyente, que profiere el contenido constitucionalmente declarado por el texto fundamental" 30 .

La misma Sala Constitucional ha precisado en sentencia posterior que el artículo 355 de la Constitución constituye también el fundamento de la fuerza vinculante de los precedentes, que se establecen por la Sala al resolver casos concretos, estableciendo al efecto:

28 López Medina, Diego. (2000). El derecho de los jueces. Santafé de Bogotá, Ed. Legis, 240 pp. p. 14 y ss.

29 Bernal Pulido (2005) 162.

30 Sentencia de la Sala Constitucional del Tribunal Supremo de Justicia de fecha 19 de julio de 2001, No 1309, Caso Hermann Escarrá. 
"A lo ya dicho conviene agregar que la doctrina que se derive de la interpretación de los preceptos constitucionales, sea que la conclusión a que arribe la Sala no resuelva un caso concreto (solicitud de interpretación), sea que aproveche a la solución de una concreta controversia en tanto contenga el modo en que los valores, principios y reglas constitucionales exigen que se tome una decisión en un sentido determinado, tiene en ambos casos efecto vinculante. Tal aclaratoria desea resolver alguna duda que pudiera surgir en cuanto al alcance de la vinculación de la función interpretativa que toca desplegar a esta Sala conforme al citado artículo 335 de la Carta Fundamental, la cual, puede que llegue a asociarse, erróneamente, a la desnuda interpretación de un precepto constitucional"31. La Sala Constitucional del Tribunal Supremo de Justicia de Venezuela en materia de ratio decidendi ha determinado:

"Las interpretaciones de esta Sala Constitucional, en general, o las dictadas en via de recurso interpretativo, se entenderán vinculantes respecto del núcleo del caso estudiado, todo ello en un sentido de limite minimo, $y$ no de frontera intraspasable por una jurisprudencia de valores oriunda de la propia Sala, de las demás Salas o del universo de los tribunales de instancia...

"Los pronunciamientos que, sin referirse al núcleo central del debate objeto de la decisión, afectan a un tema colateral relevante para la misma, normalmente vinculados con los razonamientos jurídicos esbozados para afincar la solución al caso, no serán por lógica, vinculantes, ni en este ni en otro sentido"32.

Finalmente, la Sala Constitucional del Tribunal Supremo de Venezuela ha establecido expresamente el carácter vinculante de la ratio decidendi de sus fallos, al efecto ha señalado:

"Finalmente, debido a la relevancia de las consideraciones emitidas en el fallo bajo examen y, además, por haber reflexionado la Sala sobre el alcance de principios elementales de nuestro ordenamiento juridico constitucional, como lo son el derecho a la libertad y la garantía de presunción de inocencia, declara vinculante la ratio decidendi que condujo a la decisión definitiva del presente fallo" 33 .

31 Sentencia de la Sala Constitucional del Tribunal Supremo de Justicia de fecha 5 de octubre de 2001, No 1860, Caso: Consejo Legislativo del Estado Barinas.

32 Sentencia de la Sala Constitucional del Tribunal Supremo de Justicia de fecha 9 de noviembre de 2000, No 1347. Caso: Ricardo Combellas.

33 Sentencia de la Sala Constitucional del Tribunal Supremo de Justicia de fecha 27 de noviembre de 2001, No 2426, Caso: Victor Giovanny Díaz Barón. 


\section{7) LA TIPOlOgía de SENTENCIAS QUe PUEDE DiCTAR EL TribunaL CONSTITUCIONAL DOMINICANO}

La ley No 137-11 Orgánica Constitucional del Tribunal Constitucional, en su texto, artículo 47 , se refiere expresamente a las sentencias de interpretación conforme con la Constitución; las sentencias de inconstitucionalidad parcial; las sentencias interpretativas aditivas y las sentencias exhortativas.

La ley en su artículo 47 inciso $1^{\circ}$ determina que el Tribunal Constitucional, "en todos los casos que conozca, podrá dictar sentencias interpretativas de desestimación o rechazo que descartan la demanda de inconstitucionalidad, declarando la constitucionalidad del precepto impugnado, en la medida en que se interprete en el sentido que el Tribunal Constitucional considera como adecuado a la Constitución o no se interprete en el sentido o sentidos que considera inadecuados".

El Tribunal Constitucional, de acuerdo al párrafo I del artículo 47, podrá, cuando lo estime pertinente, dictar "sentencias que declaren expresamente la inconstitucionalidad parcial de un precepto, sin que dicha inconstitucionalidad afecte integramente a su texto".

El párrafo II del artículo 47 determina que las sentencias interpretativas pueden ser "aditivas cuando se busca controlar las omisiones legislativas inconstitucionales, entendidas en sentido amplio, con ausencia de previsión legal expresa de lo que constitucionalmente debía haberse previsto o cuando se limitan a realizar una interpretación extensiva o analógica del precepto impugnado".

Finalmente, el párrafo III del artículo 47 precisa que el Tribunal Constitucional "adoptará, cuando lo considere necesario, sentencias exhortativas o de cualquiera otra modalidad admitida en la práctica constitucional comparada".

\section{8) CONCLUSIONES}

Puede sostenerse que el Tribunal Constitucional de la República Dominicana responde en el estatuto jurídico de sus jueces, a parámetros generales del Derecho Constitucional Comparado, en lo referente a número de magistrados, órganos que intervienen en el nombramiento de magistrados, duración de los magistrados en el cargo, requisitos de elegibilidad, inhabilidades e incompatibilidades, como asimismo, en la expresión de votos concurrentes y disidentes en las sentencias.

Los aspectos que podrían observarse como fuera de la regla general, afectando la autonomía del Tribunal Constitucional, están relacionados con el nombramiento del Presidente del mismo y sus sustitutos por el Consejo de la Magistratura. Otro aspecto que es poco pacífico es el sometimiento de los jueces del Tribunal Constitucional a juicio político, el cual por su práctica viciosa en las últimas dos décadas se encuentra en retroceso. 
En el ámbito de las competencias, el Tribunal Constitucional de República Dominicana se integra al elenco de Tribunales Constitucionales que determina el control preventivo obligatorio de constitucionalidad de tratados internacionales, lo que otorga seguridad jurídica de estos al momento de su integración al ordenamiento jurídico, como de respeto de las normas de los artículos 26, 31 y 27 de la Convención de Viena sobre Derecho de los Tratados. Asimismo, siguiendo una tradición latinoamericana, de la cual es excepción solo el Tribunal Constitucional chileno, el Tribunal Constitucional dominicano tiene dentro de su competencia el amparo de derechos fundamentales. Asimismo, ejerce la acción directa abstracta de inconstitucionalidad de normas jurídicas infraconstitucionales con efecto erga omnes y con modalización de efectos en el tiempo. Finalmente ejerce la potestad de resolver conflictos de competencias entre órganos constitucionales. Vale decir es un Tribunal Constitucional que tiene todo el arsenal de competencias de las jurisdicciones constitucionales contemporáneas, de lo que podríamos denominar el constitucionalismo fuerte.

Desde la perspectiva de las sentencias, es interesante, que el texto de la Ley Orgánica del Tribunal Constitucional reconozca expresamente las diferentes modalidades de sentencias que puede adoptar el Tribunal Constitucional, sentencias de interpretación conforme, sentencias de inconstitucionalidad parcial, sentencias interpretativas aditivas, sentencias exhortativas, como asimismo toda otra modalidad aceptada en la práctica constitucional comparada.

Debe destacarse que el Tribunal Constitucional dominicano se une al grupo de Tribunales Constitucionales cuyas decisiones no solo producen cosa juzgada para el caso específico, sino que "constituyen precedentes vinculantes para los poderes públicos y todos los órganos del Estado".

\section{BIBLIOGRAFÍA}

- Afonso Da Silva, Virgilio. (2004). "La interpretación conforme a la Constitución. Entre la trivialidad y la centralización judicial", en Cuestiones Constitucionales. Revista Mexicana de Derecho Constitucional. Ciudad de México. p. 21. http//www:juridicas. unam.mx/publica/rev/cconst/cont/12/ard/ard $1 . \mathrm{htm}$

- BAZÁn, Víctor. (2003). Jurisdicción constitucional y control de constitucionalidad de los tratados internacionales. Un análisis de derecho comparado. México: Editorial Porrúa.120 pp.

- Bernal Pulido, Carlos. (2005). El derecho de los derechos. Bogotá: Ed. Universidad Externado de Colombia, 419 pp.

- Biglino Campos, Paloma. (2000). "Principio de competencia, inconstitucionalidad y nulidad a la luz de la sentencia de la STC 208/1989, de defensa de la competencia”, en Revista Española de Derecho Constitucional No 59, 2000, Madrid. 
- Bocanegra Sierra, Raúl. (1981). "Cosa juzgada, vinculación, fuerza de ley de las decisiones del Tribunal Constitucional alemán”, en Revista Española de Derecho Constitucional, Volumen $1 N^{\circ} 1$, Madrid, Centro de Estudios Constitucionales.

- Escovar León, Ramón. (2005). El precedente y la interpretación constitucional. Caracas: Ed. Sherwood.

- Favoreu, Louis. (1994). Los Tribunales Constitucionales. Barcelona: Ed Ariel. 158 pp.

- Fernández Rodríguez, José Julio. (2002). La Justicia Constitucional Europea ante el siglo XXI. Madrid: Ed. Tecnos. 164 pp.

- González Beilfuss, Markus, (2000). Tribunal Constitucional y reparación de la discriminación normativa. Madrid: Centro de Estudios Políticos y Constitucionales. 356 pp.

- López Medina, Diego. (2000). El derecho de los jueces. Santafé de Bogotá: Ed. Legis. 240 pp.

- Magaloni Kerpel, Ana Laura. (2001). El precedente constitucional en el sistema judicial norteamericano. Madrid, McGraw Hill. 216 pp.

- Nogueira Alcalá, Humberto. (2006), Justicia y tribunales constitucionales en América del Sur. Caracas: Editorial Jurídica Venezolana, $313 \mathrm{pp}$.

- Rivera Santiváñez, José Antonio. (2001). Jurisdicción constitucional. Procedimientos constitucionales en Bolivia. Ed. Kipus: Cochabamba, 540 pp.

- Rubio Llorente, Francisco y Jiménez Campo, Javier. (1998). Estudios sobre Jurisdicción constitucional, Madrid: MacGraw-Hill, 173 pp.

- Schäfer, Heinz, (1998). "Austria: la relación entre el Tribunal Constitucional y el Legislador" en Aja, Eliseo (ed.). Las tensiones entre el Tribunal Constitucional y el Legislador en la Europa Actual, Barcelona, Ariel derecho, 300 pp.

- Tejedor Bielsa, Julio. (1999). "Inconstitucionalidad y nulidad demorada ¿paliativo a la nueva jurisprudencia sobre supletoriedad? La STC 195/1998, de $1^{\circ}$ de octubre". En Revista Española de Derecho Administrativo, No 101, 1999.

- Tupayachi Sotomayor, Johnny (coord). (2009). El precedente constitucional vinculante en el Perú (análisis, comentarios y doctrina comparada). Lima: Ed. Adrus - Instituto Iberoamericano de Derecho Constitucional, sección Peruana. 869 pp.

- Würtenberger, Thomas. (2005). "Interpretación del Derecho Constitucional (desde una perspectiva realista)". En Ferrer MacGregor, Eduardo (Coord). Interpretación Constitucional. Tomo II, Ciudad de México: Ed. Porrúa. 